\title{
Soils, landscapes, and cultural concepts of favor and disfavor within complex adaptive systems and ResourceCultures: human-land interactions during the Holocene
}

\author{
$\underline{\text { Bruce R. James }}^{1}, \underline{\text { Sandra Teuber }}^{2,3}, \underline{\text { Jan J. Miera }}^{4,5}, \underline{\text { Sean Downev }}^{6,7}, \underline{\text { Jessica Henkner }}^{2}, \underline{\text { Thomas Knopf }}^{8}, \underline{\text { Fabio A. Correa }}^{7}$, Benjamin $^{2}$

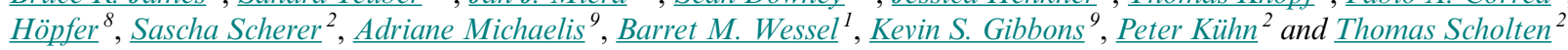

\begin{abstract}
We review and contrast three frameworks for analyzing human-land interactions in the Holocene: the traditional concept of favored and disfavored landscapes, the new concept of ResourceCultures from researchers at University of Tübingen, and complex adaptive systems, which is a well-established contemporary approach in interdisciplinary research. Following a theoretical integration of fundamental concepts, we analyze three paired case studies involving modern agriculture in Germany and Belize, prehistorical changes in land use in southwest Germany, and aquaculture on the Pacific and Atlantic coasts of North America. We conclude that ResourceCultures and complex adaptive systems provide different but complementary strengths, but that both move beyond the favordisfavor concept for providing a holistic, system-level approach to understanding human-land interactions. The three frameworks for understanding human responses to contemporary cultural and biophysical challenges are relevant to new thinking related to sustainability, resilience, and long-term environmental planning in the Anthropocene.
\end{abstract}

Key Words: Black Forest agriculture; Bronze Age land use in Germany; Chesapeake Bay oyster culture; complex adaptive systems; German allotment gardens; human-environment interactions; Pacific Northwest clam gardens; Q'eqchi' Maya swidden agriculture in Belize; ResourceCultures

\section{INTRODUCTION}

In this paper we review and contrast three frameworks for analyzing human-land interactions in the Holocene. The first is the traditional concept of favored and disfavored landscapes, which has a long intellectual history. The second framework, ResourceCultures, attempts to supersede the binary limitations of the traditional favor-disfavor concepts by introducing a flexible definition of resources that includes both tangible elements such as raw materials and intangible ones such as power and knowledge. The third framework views human-land interactions as decomposable, and instead of providing an interpretivist framing, it views them as complex adaptive systems that have unique system-level properties that emerge out of nondeterministic, contingent low-level interactions among human and nonhuman agents. This study results from an interdisciplinary collaboration between archaeologists, ecological anthropologists, soil scientists, and ethnographers from Germany and the United States; and our key discovery is that both ResourceCultures and complex adaptive systems overcome many of the key limitations of the earlier favor/disfavor framework. Although the ResourceCultures and complex adaptive systems frameworks derive from contrasting interpretivist and empirical intellectual histories, respectively, they have many qualitative similarities, including a shared focus on dynamic feedbacks between elements of the human-land system and a particular emphasis in explaining historical patterns and nondeterministic change, rather than simple classification. In this paper, we use this insight as a point of departure for analyzing the usefulness of each framework for explaining actual contemporary and archaeological landscapes.

Our approach involves five stages: (1) we review, compare, and contrast the key concepts and historical background associated with each of the three frameworks; (2) we identify key concepts from each framework and develop a protocol for assessing the utility of each for analyzing specific cases; (3) we then draw on the diverse expertise of the coauthors to analyze six, well-studied cases spanning contemporary and archaeological landscapes across Europe and the Americas according to these criteria; (4) we present the results of these analyses as three paired comparisons; and (5) we discuss the key concepts in order to highlight the strengths and weaknesses of each framework for understanding dynamic settlement patterns and resource use among particular types of human-land systems.

\section{Three theoretical frameworks for analyzing human-land} interactions in the Holocene

Favorable and disfavorable landscapes

Landscapes can be understood as geographic areas that are divided into reasonably well-defined spatial components, distinguished by ecological and cultural attributes that are relevant to soils and human uses of the land (Potschin and Bastian 2004, Pearson 2013, Wu 2013). They are typically defined by their environmental attributes, such as topography, climate, soils, wetlands, native plant communities, or other environmental

\footnotetext{
${ }^{1}$ Department of Environmental Science and Technology, University of Maryland, College Park, MD USA, ${ }^{2}$ Department of Geosciences, Faculty of Science, University of Tübingen, Tübingen, Germany, ${ }^{3}$ SFB 1070 ResourceCultures, University of Tübingen, Tübingen, Germany, ${ }^{4}$ Institute for Preand Early History, University of Leipzig, Leipzig, Germany, ${ }^{5}$ Institute for Pre- and Early History, Friedrich-Schiller-University Jena, Jena, Germany, ${ }^{6}$ The Sustainability Institute at Ohio State University, Columbus, OH USA, ${ }^{7}$ Department of Anthropology, The Ohio State University, Columbus, OH USA, ${ }^{8}$ Institute of Pre- and Protohistory and Medieval Archaeology, University of Tübingen, Tübingen, Germany, ${ }^{9}$ Department of Anthropology, University of Maryland, College Park, MD USA
} 
characteristics. They may contain culturally important places, and therefore are not only defined by environmental conditions, but are imbued with social, religious, and political attributes by the people using and perceiving the land. In this sense, landscapes are a product of past human use of and cultural connections to the land (McGlade 1995, Hambrecht et al. 2020). They may also be understood as socially constructed objects of analysis and individual interpretation (Tilley 1994, Bender et al. 2007).

The concepts of favorable or disfavorable landscapes do not refer to an intrinsic property of a physical landscape but rather to the suitability of a landscape to be used for a certain typically human purpose, e.g., grain crop agriculture. For example, a minimum mean temperature of $6^{\circ} \mathrm{C}$ for six consecutive months is needed to grow and harvest certain grain crops, and this climate-related criterion has been used to differentiate between agriculturally favored and disfavored landscapes (Bourke 1984). In central Europe, the concept traditionally refers to environmental conditions during the settlement period of a region (Seidl 2006, Gebhardt 2007). Favored landscapes are often loess covered, possess fertile soils, low relief intensity, and a climate beneficial for agriculture. These landscapes were therefore supposedly settled earlier than disfavored ones without such beneficial features (Seidl 2006, Henkner et al. 2017, Kühn et al. 2017). Other terms for disfavored landscapes are marginal land, degraded land, waste land, upland, hinterland, or outland. These terms connote particular economic and social systems that were not sustainable and were viewed as static landscapes (Brown et al. 1998, Coombes and Barber 2005, Dauber et al. 2012).

Historically, the dichotomous categorizing of landscapes as favored or disfavored was based solely on the agricultural potential or the workability of soils, while not acknowledging important cultural aspects influencing the settlement dynamics of a region. In contemporary studies, the favor/disfavor categorization was also seen as problematic, which led to the development of the additional related concepts such as territoriality, marginality, and liminality, which broaden favorability (and disfavorability) to include culturally determined concepts. Marginality, for example, focuses on human perceptions and valuation of space. Territoriality refers to social power and the control over space by certain groups or individuals, and liminality refers to the transition or buffer zones that separate better organized and controlled spaces. Any physical space can have multiple overlapping aspects of these concepts. Because it can be perceived and used differently by individuals or groups, the practical and symbolic uses of a space can intersect (Neuburger 2017), and territorialities can vary in time (Miera 2020). Although these approaches show that the definition of a landscape as favored is always dependent on the culturally defined needs and the perception of people, the dynamics behind such processes are not extensively evaluated. Thus, the simplistic and static terms favor and disfavor remain insufficient for explaining dynamic historical and modern uses of and decision making about landscapes.

For example, the successful introduction of hexaploid wheat (Triticum aestivum) and tetraploid emmer (Triticum turgidum subsp. dicoccum and conv. durum) into continental Europe starting in the early 5th millennium BCE may have shifted landscapes disfavored because of a lack of wild game for hunting into favored ones that could then be exploited agriculturally for grain production. Similarly, agriculture might have lost its importance when other culturally desirable and economically profitable raw materials like silver, iron, or gold were found beneath the land surface. The landscape would then be favored for mining and exploitation of raw materials, but not for agriculture. As a result, landscapes could have been disfavored agronomically, but favored as sources of geological resources, wood, or water. The favor-disfavor classification is clearly insufficient for understanding how and why humans used and changed such landscapes over millennia.

\section{ResourceCultures}

To develop a new paradigm of resource, interdisciplinary scholars from archaeology, cultural anthropology, soil science, and related disciplines formed the Sonderforschungsbereich 1070 ResourceCultures (RC) at the University of Tübingen (Bartelheim et al. 2015, Hardenberg 2017a, b, Hardenberg et al. 2017). The SFB 1070 offers a new perspective on resources with the focus on their importance for social relations. The following characteristics are central to the paradigm:

1. Both tangible, e.g., raw materials and soils, as well as intangible things, e.g., knowledge and social structures, can be defined as resources.

2. All material and nonmaterial things are resources if they are important for the formation, maintenance, and transformation of social networks, communities, and identities.

3. Resources are defined as an analytical category with a constructivist perspective. Nothing is intrinsically a resource for the formation of identities and social relations. Instead, cultural perceptions and practices lead to the valuation of certain elements within social groups, thereby turning these into resources for this group.

4. Culture is defined as a contingent spectrum of possibilities, a diversity of conceptions, organizational forms, and practices. Because the perception and use of resources in a society is constantly changing, dynamic relationships evolve. These dynamics result in the emergence of new resources while other tangible or intangible things lose their status as a resource (Hardenberg 2017a, b, Hardenberg et al. 2017).

An example of constantly changing and dynamic relationships between resources and other elements can be found in medieval monasteries in southwest Germany, where spirituality became an important resource for the monks and the nobility (Krätschmer et al. 2018). This is indicated through the dynamics of social relations between nobility and monks, which is based on the transformation of tangible objects into important intangible resources for certain members of medieval societies, namely the conversion of donations of land by the nobility into eternal salvation for the gifting through prayers by the monks. However, in today's societies, these prayers have lost their importance and new resources came into being.

5. Societies, of course, have multiple resources, as defined above. However, other elements are needed to enable the use of a specific resource. These combinations of objects, knowledge, practices, and individuals can be analyzed using so-called ResourceComplexes. This analytical device allows the identification of elements that 
interact to make use of a resource such as soil or that enable the settlement of a region.

An example of a ResourceComplex is the establishment of the settlements associated with the ditched enclosures of Azután in Spain during the Later Prehistory of Central Iberia, which required several different resources (Schmitt 2017). These resources, e.g., fertile soil, crop plants, and domesticated animals, interacted with other elements of the environment and the contemporary society forming a ResourceComplex that enabled the settlement of the region. As part of a ResourceCulture, the ResourceComplex approach connects resources with social, political, and religious relationships and identities in a meaningful way (Hardenberg 2017a, b, Hardenberg et al. 2017). These new ideas aid in the study and analysis of both culture and timespecific perceptions and dynamic uses of landscapes.

Complex adaptive systems

Complex adaptive systems (CAS) is an interdisciplinary framework for studying social and natural systems that incorporates insights about the fundamental unpredictability that characterizes most systems (Castellani 2013). The recognition that an alternative to earlier equilibrium-based approaches was needed arose in the early 1970 s, when mathematical ecologists discovered that even the simplest biological models could exhibit extremely complex and chaotic behavior (May 1974a, b, 1976). Simple explanations for more complex systems, such as empirical animal population dynamics (Odenbaugh 2011) or human demographic patterns (Liu 2001), appeared unreliable. This increased interest embraced the complexity of systems, rather than eliminating it, and it exposed the shortcomings of earlier reductionist approaches (Coffman 2011, Moreno et al. 2011). The broad concept of complex adaptive systems has thus emerged as a way to characterize and analyze systems that exhibit complex and unpredictable dynamics and patterns of behavior (Lansing 2003). Complex adaptive systems are characterized by nonequilibrium states and nearly constant change and reinvention over time. In anthropology, this idea led to prioritizing human agency and a constructivist view of nature (Scoones 1999), and to the recognition that most landscapes are dominated by human activity (Balée 2006). However, the impact of CAS on the development of methods and theory for understanding coupled dynamics of human-natural systems has been relatively small until recently (Liu et al. 2007, Bird 2015).

Complex adaptive systems consist of numerous parts interacting across multiple scales in space and time that comprise humans, animals, plants, soils, water, and other systems. Some of these elements accumulate experience and adapt by changing their modes of behavior, resulting in some form of success, reward, or survival (Holland 1995, 2014, Mitchell 2009). These systems have several common characteristics:

1. Emergent properties: Colloquially, emergence refers to the idea that the whole is more than the sum of its parts (Fisher 2009), but in more formal terms, emergent properties include chaotic behavior, feedback dynamics, regular patterns in space and time, and self-organization of the system into hierarchies and classes in the absence of any form of centralized control (for examples, see Lansing 2006, 2007, Lansing and Downey 2011).
2. Domination by nonequilibrium states: Equilibrium states exist when aspects of a system balance one another, but it is now understood that most complex adaptive systems are dominated by nonequilibrium states (Lansing 2003). These can be steady states, low entropy states, or self-organized states that are maintained by the input of energy and resources to maintain them in a certain condition for some period of time. If the input of energy is stopped, natural processes will drive the system to one with higher entropy and more possible degrees of disorganization.

3. Scale in space and time: Systems may also be affected by inputs across a range of spatial (e.g., local to global relationships) and temporal scales (e.g., daily household interactions, annual rainfall variation, or decadal/centennial climate change; Levin 1992).

4. Feedback relationships: When subsystems interact and respond to each other, the trajectory of the CAS evolves in unpredictable directions. Ecosystems change in response to the stress imposed by human use, and human societies adjust their behavior in response to perceived changes in these systems; in turn, this changes the stress imposed on ecosystems (Scheffer et al. 2002). The result of feedback relationship is nonlinear system dynamics, which is a hallmark of most CAS.

5. Regime shifts: Triggers are driving forces, e.g., key historical events, when system thresholds are exceeded. Typically, most CAS can exist in a variety of different regimes, where the same essential elements are rearranged in importance of position in a hierarchy. The capacity of a system to absorb disturbances without experiencing a regime shift is known as resilience (Gunderson and Holling 2002), but when thresholds are exceeded, regime shifts occur. Regime shifts can be defined as changes in the structure and function of ecosystems or societies between regimes, where these changes can be large, abrupt, persistent, and difficult to reverse (Biggs et al. 2012). Examples of regime shifts on regional scales are population collapses, mass migrations, and desertification processes, which can be caused by population feedbacks, dramatic environmental change, warfare, disease, or complex interactions among these phenomena (Downey et al. 2016).

The three frameworks for analyzing human-land interactions are compared and contrasted in Table 1. In general, we note several differences. First, the favor-disfavor framework is poorly suited for empirical research because of the subjectivity inherent in the dichotomous classification process. Its intellectual history suggests the concept itself developed slowly, and was mainly derived from preconceived notions about agricultural suitability that embodied a strong Eurocentric bias. In contrast, both RC and CAS are intentional "frameworks" that were designed to solve a suite of known intellectual and logical problems in analyzing human-land interactions. $\mathrm{RC}$ and CAS each strive to be comprehensive and generalizable, whereas the historical favordisfavor framework does not. The CAS framework is well suited for empirical research (data collection, analysis, and modeling) because it provides an approach composed of subunits and higher order system properties that can be used for understanding the emergent properties of coupled human and natural systems. CAS has already made important contributions to the study of human 
Table 1. Three systems for evaluating landscape change and human impacts.

\begin{tabular}{|c|c|c|c|}
\hline Attributes & Favor/Disfavor & ResourceCultures & Complex Adaptive Systems \\
\hline Dynamic vs. static? & Static and dichotomous & $\begin{array}{l}\text { Dynamic within interpretive framework } \\
\text { for resources }\end{array}$ & Dynamic in time and space \\
\hline Quantifiable? & $\begin{array}{l}\text { Difficult to quantify; relies on human } \\
\text { interpretation }\end{array}$ & $\begin{array}{l}\text { Subjective in interpretation of resource } \\
\text { change and definition }\end{array}$ & Quantifiable using multiple attributes \\
\hline Ecological vs. cultural & Principally ecological & Both & Both \\
\hline Theoretical basis & $\begin{array}{l}\text { Historical use by ecologists, soil } \\
\text { scientists, and anthropologists for last } \\
200 \text { years in Europe }\end{array}$ & $\begin{array}{l}\text { Newly proposed, interpretive basis in } \\
\text { soil science, and anthropology; } \\
\text { redefining the concept of "resources" }\end{array}$ & $\begin{array}{l}\text { Based on ecology and anthropology } \\
\text { principles since } 1970 \text { s; emerging from } \\
\text { empirical studies of ecosystem and } \\
\text { cultural change }\end{array}$ \\
\hline Practical applications & $\begin{array}{l}\text { Easily applied, based on traditional } \\
\text { ways of interpreting landscapes }\end{array}$ & $\begin{array}{l}\text { Currently being applied in } \\
\text { interdisciplinary studies }\end{array}$ & $\begin{array}{l}\text { Widespread tool in modern and } \\
\text { historical case studies of human-land } \\
\text { relationships }\end{array}$ \\
\hline
\end{tabular}

cultural change and ecological dynamics (see examples above). The more recent ResourceCultures framework is a way to define and understand human activities on landscapes and also grapples with dynamic feedbacks among tangible and nontangible aspects of the human-land system, but in a more flexible interpretivist framework. The valuation of resources by resource users is a central element of RC that allows dynamic, cultural processes in space and time, for example, power, knowledge, and religion, to be included in the analysis of human-land interactions in the Holocene.

In the next section, we use these three frameworks to interpret and analyze six case studies from Germany and the United States that describe human-landscape interactions during the Holocene. The case studies were paired, based on the similarities of the landscapes or their human uses.

\section{APPROACH}

We posit that the CAS and the RC frameworks are more tenable than the favor-disfavor dichotomy for understanding dynamic human-land interactions on diverse landscapes and soils in historical contexts; however, the strengths and weaknesses of each approach, respectively, are less clear. To explore how CAS and $\mathrm{RC}$ frameworks provide a dynamic way of refining the concepts underlying favor and disfavor, we conducted a comparative analysis of three pairs of related case studies in the context of the key attributes of CAS, described below. The pairs were selected based on similarities of human uses of a landscape and time period in the Holocene. In each case, differences and similarities between the results using CAS vs. RC provided an effective and heuristic way to refine or replace the static dichotomy of favordisfavor. For each pair of case studies, each of the landscapehuman systems was evaluated qualitatively for the following attributes: "

1. Nature of land use investigated (contemporary or archaeological)"

2. Favorability/unfavorability (has the system been previously defined exogenously, endogenously, or both)"

3. Scale of the investigated system in space and time (small: local/months to years; medium: regional/years to centuries; large: geographic units/decades to millennia)"
4. System boundaries (clearly or poorly defined)"

5. Adaptation (individual or community level adaptation, adaptation through policy, or both)"

6. Out-of-equilibrium conditions within the studied system (yes or no)"

7. Social and natural feedback effects within the analyzed system (yes or no)"

8. Evidence of emergence (local interactions, self-organization into hierarchies, unexpected/unexplainable system-level properties) within the investigated system (yes or no)"

9. Alternative regimes possible (yes or no)"

10. Are there material or symbolic triggers in the investigated system that have or could trigger regime shifts (yes or no)

\section{Summaries of the pairs of case studies}

The first pair of case studies examines modern, small-scale food production in Belize and Germany. The integrated socialecological swidden agriculture system used in Q'eqchi' Maya communities in Belize is dominated by tropical swidden agriculture and open access to land by community members (Downey 2015). Modern urban gardening practiced by German people in two regions in temperate southwest Germany (Teuber et al. 2019) uses land that is leased from the municipality where one-third of the area has to be cultivated with foodstuffs (BKleingG 1983). Both systems have contrasting native vegetation, climates, soils, cultural histories, and land use.

The second pair compares historical and prehistorical agricultural practices in the Black Forest (Knopf et al. 2020), and settlement dynamics in southwest Germany (Henkner et al. 2018). The Black Forest was only used locally during prehistory, but during medieval times, it was systematically developed with the intensive use of wood and self-sufficient agriculture. In the 16th century, the massive expansion of agriculture into higher mountainous regions occurred; then, starting in the 20th century, arable farming was almost completely abandoned (Knopf et al. 2020). The case study on Bronze Age land use in southwest Germany focuses on three regions, the Baar, the Hegau, and the Allgäu, where settlements and their surrounding land are being investigated archaeologically and from the perspectives of soil science (Scherer et al. 2021). Both case studies focus on different 
Table 2. Summary of case study data evaluated under the rubric of complex adaptive systems criteria.

\begin{tabular}{|c|c|c|c|c|c|c|}
\hline $\begin{array}{l}\text { Criteria (see text for } \\
\text { detailed criteria) }\end{array}$ & $\begin{array}{l}\text { Q'eqchi' Maya } \\
\text { Swidden } \\
\text { Agriculture } \\
\text { (Belize) }\end{array}$ & $\begin{array}{l}\text { Urban Gardening } \\
\text { in SW-Germany }\end{array}$ & $\begin{array}{l}\text { Agriculture in } \\
\text { the Black Forest }\end{array}$ & $\begin{array}{l}\text { Bronze Age land } \\
\text { use in SW- } \\
\text { Germany }\end{array}$ & $\begin{array}{l}\text { Clam Gardens on the } \\
\text { Pacific Northwest } \\
\text { Coast (Canada) }\end{array}$ & $\begin{array}{l}\text { Maryland Oyster } \\
\text { Management } \\
\text { (Chesapeake Bay, U.S.) }\end{array}$ \\
\hline $\begin{array}{l}\text { 1. Nature of land use } \\
\text { investigated }\end{array}$ & Contemporary & Contemporary & Archaeological & Archaeological & Archaeological & Contemporary \\
\hline $\begin{array}{l}\text { 2. Favorability/ } \\
\text { unfavorability }\end{array}$ & Both & Exogenous & Exogenous & Exogenous & Both & Both \\
\hline $\begin{array}{l}\text { 3. Scale of the investigated } \\
\text { system in space and time }\end{array}$ & Small & Small & Medium & Large & Medium & Medium \\
\hline 4. System boundaries & Clearly defined & Clearly defined & Clearly defined & Poorly defined & Clearly defined & Clearly defined \\
\hline 5. Level of adaptation & $\begin{array}{l}\text { Individual \& } \\
\text { community }\end{array}$ & $\begin{array}{l}\text { Individual \& } \\
\text { community }\end{array}$ & $\begin{array}{l}\text { Individual \& } \\
\text { community }\end{array}$ & $\begin{array}{l}\text { Individual \& } \\
\text { community }\end{array}$ & $\begin{array}{l}\text { Individual \& } \\
\text { community }\end{array}$ & $\begin{array}{l}\text { Both individual and } \\
\text { policy-level adaptation }\end{array}$ \\
\hline $\begin{array}{l}\text { 6. Out-of-equilibrium } \\
\text { conditions within the } \\
\text { studied system? }\end{array}$ & Yes & Yes & Yes & Yes & Yes & Yes \\
\hline $\begin{array}{l}\text { 7. Social and natural } \\
\text { feedback effects within the } \\
\text { analyzed system? }\end{array}$ & Yes & Yes & Yes & Yes & Yes & Yes \\
\hline 8. Evidence of emergence? & Yes & Yes & Yes & Yes & Yes & Yes \\
\hline $\begin{array}{l}\text { 9. Alternative regimes } \\
\text { possible? }\end{array}$ & Yes & No (and Yes) & Yes & Yes & Yes & Yes \\
\hline $\begin{array}{l}\text { 10. Are there material or } \\
\text { symbolic triggers? }\end{array}$ & Yes & Yes & Yes & Yes & Yes & Yes \\
\hline
\end{tabular}

areas in the sense of physical geography, but they have similar spatial and temporal dimensions, and similar cultural traditions, regional climates, and human histories.

The third comparison is based on landscapes in shoreline ecosystems, with a case study on clam gardens on the Pacific Northwest Coast of North America, and another on Maryland oyster management in the Chesapeake Bay. The clam gardens illustrate a type of niche construction in shallow coastal areas, where First Nations built broad, shallow, sandy areas as clam gardens for subsistence aquaculture (Deur et al. 2015). The case study in the Chesapeake Bay investigates submerged land and its use in the form of privately leased bottom through state approved oyster aquaculture. These case studies highlight the land-water interface and its importance in the history of North America and modern practices for gathering clams and oysters.

\section{RESULTS}

The results of each pairwise comparison of case studies are summarized in Table 2, as they pertain to the specific attributes of CAS. Relationships with RC and ResourceComplexes are in the text descriptions that follow. Table A1.1 contains more detailed information about each of the criteria as it was solicited from each case study specialist.

\section{Maya agriculture in tropical Belize and urban gardening in temperate Germany}

Comparing perceptions of favored landscapes in tropical Belize and temperate Germany highlights similarities defined by soils or climate, and shows differences in culture. In both case studies, a favored status has been defined relatively, without exploring human capacity to adapt to the physical environment. The soils in the Toledo District were seen historically (by non-Maya outsiders) as less favored for swidden (slash-and-burn) agriculture than the soils of Alta Verapaz, Guatemala, the Q'eqchi' homeland, where soils were ostensibly richer. In the German case study, highly favored conditions are not related to soils but rather depend on climatic and spatial aspects. The latter are related to cultural dependencies, with the hierarchical gardening associations in Germany depending on federal and municipal decisions to assign them gardening areas. In contrast to this allotment garden space, Belize swidden-related land use decisions are made at the level of individual households.

The CAS framework generated several useful insights about these two case studies. World Wars I and II in 20th century Europe may have acted as a trigger for changes concerning horticultural land use in German cities and towns (Nilsen 2014), while 19th century social and political oppression by the liberal government of Guatemala may have had significant effects on the use of swidden in Belize by triggering the migration of indigenous communities fleeing such oppression. In Belize and Germany, both cultural and ecological feedbacks may have established new steady states or quasi-equilibria in response to war and political oppression that are important today for community-level political control and food production. In both cases, physical and chemical soil changes may have been less important than social and political factors.

Emergent properties and epiphenomena were also noted in both cases. In Belize, village labor exchange networks exhibit unexpected levels of hierarchy and connectivity despite the absence of top-down coordination of agricultural activities. Similarly, in Germany, emergent hierarchies appear to exist as all gardens participate in a local association that is part of the regional and the national allotment garden association. Further, as in Belize, where alcaldes (village policemen) rarely intervene in day-to-day agricultural activities, the allotment spokespersons in Germany monitor the gardening practices of the individual gardeners only on a yearly basis to ensure that at least one third 
of the area is dedicated to food production as is required by law (BKleingG 1983). However, on a day-to-day basis, individual decisions, networks between the gardeners, and exchange of plants, knowledge, and sometimes even tools, shape the allotment garden system.

Comparing the Belize and German case studies is informative because both studies ended up with similar observations about the emergence of local agricultural or horticultural production, despite differences in their overt cultural and theoretical frameworks. The Belize case study began with CAS as an organizing framework, while the German case study began by using the ResourceComplex concept to identify system variables in a particular study site. This latter approach was developed to enable interdisciplinary research, and therefore does not determine which theoretical approach is used afterward. Thus, the German case study ultimately analyzed the allotment system in the context of a coupled human and natural systems framework that incorporates many of the key insights about complexity and emergence from CAS theory (Gunderson and Holling 2002).

The appearance of the German allotment association during the interwar period could be hypothesized as an emergent effect of a specific set of historical social and environmental circumstances related to the war. Under this scenario, the postwar need for urban subsistence would have set the initial conditions by converting areas suitable for allotments into gardens so that over subsequent decades individual allotment garden areas could evolve into the nationwide network as described in the case study. The historical context, of course, changed dramatically and unpredictably from the postwar period to today when being outdoors and having healthy nutrition have become more important motivations than subsistence. Similarly, in Belize, historical political oppression in Guatemala led to Q'eqchi' migration into southern Belize. After this trigger event, the initial conditions were set and individual and household-level decisions related to subsistence and wagelabor eventually led to a complex system of village administration characterized by low levels of agricultural oversight, high levels of household independence with respect to land use, and to land use norms related to subsistence-oriented swidden that encouraged sustainability (Downey 2010).

Concepts of favor/disfavor were manifested in both studies as differences in soil fertility in Belize and different climatic conditions in Germany. However, in both cases the regions that have been perceived as disfavored were ultimately considered favored because of the adaptive ability of local famers or gardeners. Thus, in comparing the German and Belize case studies, it appears that RC and CAS can be complementary approaches. The element-identification process encouraged by the $\mathrm{RC}$ framework was amenable to interpretation under the key concepts provided by CAS.

\section{Black Forest agriculture and Bronze Age land use in southwest Germany}

In traditional research, perspectives of the Black Forest, the Baar, the western Allgäu, and the Hegau as favored and disfavored regions were based on parameters such as elevation, average temperature, amount of precipitation, and soil quality. As a result, a Western, nature-deterministic perspective predominates the assessment of a landscape's suitability for prehistoric and premodern land use. There is little direct evidence supporting whether prehistoric and premodern farmers used similar arguments to evaluate their daily subsistence or whether their decision-making processes regarding favored and disfavored land was guided by more complex parameters and changes over time.

Seen from a CAS perspective, the Black Forest region had unpredictable dynamics: the periods of stability were temporary, and people adapted their behavior in response to social and environmental changes. Although there probably was no centralized authority organizing the transition of mountain forests into fields, a kind of shared organization and agreement must have existed to manage the intensive labor needed for this task. Driving forces behind Black Forest dynamics were likely sociopolitical changes that allowed people to turn the land held as commons into arable fields and other productive agricultural land, as well as an increased population and its associated demand for food.

There must have been a kind of stability in the social and ecological dynamics of the food producing system, allowing people to live continuously in the Black Forest since the Middle Ages. This could be understood as an emergence with regular patterns of land management, self-organization, feedback relationships between farmers and their labor organization, and unstable natural conditions, e.g., with hard winters, late frosts, or heavy rains. The system involved also a certain degree of resilience to minor climatic challenges, e.g., cold and rainy summers; but constant small-scale adaptations of subsistence management were necessary, including the development of specialized handicrafts starting in the 18th century, e.g., cuckoo clock production and trade. The construction of stone mounds was an output of a specific land use that could be considered an emergent property resulting from the above-mentioned triggers (nascent commons and population increase). But it obviously worked only for a certain time before new triggers, e.g., industrialization, led to new adaptations.

The RC framework helps to expand perceptions of natural resources by highlighting the importance of intangible resources. Within this framework, the definition of ResourceComplexes as an analytical tool of RC and interactive networks can express the complexity of interrelations between tangible and intangible needs based on time-specific human perceptions. From an RC perspective, the Black Forest offered some resources that were seen as favored depending on time, scale, and specific culturally determined resource use. Concerning the stone mounds and the agriculture on higher ground, this went beyond creating new fields or producing more food. Sunny slopes above cold air pockets at lower elevations, better soils, and an intensive workload turned the formerly disfavored resource of higher ground and slopes into a favored landscape, at least for a certain time. But we can also assume that human societies assigned symbolic meaning to the clearing of forests, the building of terraces, and the constant input of labor in starting and maintaining these areas. This could be the positive effect of overcoming the limitations of natural conditions by creating new possibilities of food production.

The study of Bronze Age land use in southwest Germany shows that it was apparently not primarily dependent on physicalgeographic parameters. At certain times, favored regions like the inner Hegau were hardly used, while disfavored ones like the Baar 
or western Allgäu were densely settled; therefore, the Bronze Age subsistence lifeways were characterized by great adaptability. It also seems likely that intangible motives like trade and communication or social/political factors might have played a decisive role. According to the RC framework, the accessibility of settlements could have been as much a resource as fish, firewood, or fertile soil. A shift of settlement from the lakes as topographic nodal points to connective inland-corridors like the Baar or western Allgäu means that the resource accessibility underwent a change.

In terms of CAS, the increasing orientation toward trading routes during the Bronze Age can be seen as an emergent property as well as a regular pattern or continuum. The effort put into the maintenance of stable exchange networks by adjusting to the environment of new, and maybe more demanding, areas emphasizes the nonequilibrium state of the land use system. Because there is no clear evidence for any kind of centralized decision making affecting all of the southwestern German landscape units, the formation of various site types - fortified and unfortified lakeshore settlements, hilltop sites, and inland settlements - attests to a self-organization of the settlement network at a local scale. Because of the typically vague chronology of prehistoric developments, however, it is hard to pinpoint specific feedback relationships. Dramatic climate change can be seen as the trigger for the abandonment of the immediate lake shores, but it is not an adequate explanation for inland shifts of many kilometers and an abandonment of previous nodal points. Thus, it seems likely that other impetuses were eventually overcoming the systems' resilience at a certain threshold. Following the logic of the CAS framework, the system's dependence on interregional exchange might indicate external developments, such as a new political organization of supplies and their distribution as possible triggers or regime shifts.

Both case studies deal with past human-nature interactions while mostly or entirely lacking written records. Interpretations are generally dependent on the quality of material sources, the chronological placement, and the context. Thus, both theoretical perspectives, CAS and $\mathrm{RC}$, provide a more differentiated perspective on favor/disfavor. The latter leads away from simple economic and natural resources to incorporate the importance of a complex set of tangible and intangible resources influencing human land use. The concept of CAS highlights that behind the extension of land use or the shift of settlements, dynamic adaptive systems are hidden. These organically grown, chaotic, and unruled systems are able to react to strong external stimuli and to adjust to changing sociopolitical and environmental changes. The CAS framework also reminds us to evaluate the internal potential for spontaneous changes and, if necessary, to check for external triggers or regime shifts.

CAS and RC disrupt and build on the traditional dichotomy of favor/disfavor concepts and offer other options to interpret how people were acting in and perceiving their landscapes. They also provide insight on how the inhabitants unconsciously changed their land use practices because of internal and external, tangible and intangible factors.

\section{Kwakwaka'wakw clam gardens and Maryland oyster management}

The comparison of Kwakwaka'wakw clam gardens and Maryland oyster management highlights shellfish aquaculture taking place on opposite sides of the North American continent, supporting the cultural and spiritual identity of two different cultures. Kwakwaka'wakw clam culture began over 1000 years ago and largely ended after contact with Europeans led to epidemics that devastated extant human populations. Limited clam culture continued into the early 1900s. At that time, Maryland began a century of oyster management, but continued to vacillate with regard to oyster aquaculture. In both cases, favor/ disfavor is subjective and malleable. The Kwakwaka'wakw used submerged land that they could adapt, rendering it favored for clam gardens. Knowledge of clam gardening has been preserved in songs and other oral traditions for centuries or longer, describing not only the technology of clam culture but a cosmology that saw humans and clams as sharing a mutually beneficial relationship since the beginning of time, each in a way partially responsible for the well-being of the other and interacting with the rest of nature in similar ways. Today, efforts to revive clam gardens and other foodways are central to historic and cultural preservation in these communities. In Maryland, bottom that may be deemed disfavored by its barren description is contested by multiple user groups, one of which aims to convert barren bottom into productive oyster bottom via oyster aquaculture. Both cases highlight shifting notions of favor and disfavor, achieved through human practices. In the case of the Kwakwaka'wakw, members actively manipulated shallow coastal areas to create habitat suitable for clam growth. In Maryland, privately leased bay bottom is prepared with shell to grow oysters directly, or containers are used to hold and grow oysters just off the bottom. In both cases, perceived favorability is linked to the spiritual and cultural value of these shellfish resources, which continue to provide livelihoods that yield myriad cultural benefits, with significant contributions to individual and community identities through heritage, sense of place, and stewardship as well as enhanced experiences and capabilities enabled through relationships with these shellfish and landscapes (Michaelis 2020, Michaelis et al. 2020, Wessel 2020).

Considering each case study within the framework of RC, two scenarios focus on a tangible resource, the clam and the oyster, respectively, but also on intangible ones. In both cases, the bivalves provide a source of food directly or indirectly. Less tangibly, these bivalves are also spiritually significant for the Kwakwaka'wakw and historically important to the culture of Maryland. The sociopolitical importance of oysters expands their recognition as a resource. The $\mathrm{RC}$ framework also allows us to view the legal and regulatory systems for managing these bivalves as resources. The Kwakwaka'wakw had no legal prohibition on modifying coastal areas for clam gardens, so they likely did not view aquaculture as being in conflict with navigation. In Maryland, aquaculture activities are regulated, and it can be difficult to site an oyster plot on suitable barren bottom. Even if permission is obtained, major bottom alterations such as the Kwakwaka'wakw implemented are still legally prohibited in Maryland. Although there is justification for the current legal and regulatory system in Maryland, it may not be fostering shellfish aquaculture as effectively and equitably as it could be. As individuals change the way they interact with their resources, the potential exists for shifting and dynamic identities, practices, and communities.

Applying the CAS framework reveals that each case is well-suited to using it; however, certain characteristics prevent full recognition of CAS details. Both cases are challenged by limited 
knowledge, but with opposite time constraints. For Kwakwaka'wakw clam gardens, detailed historic data are lacking. For Maryland oyster management, additional time is needed to observe the system-wide effects of more recent policy changes. Both cases demonstrate out-of-equilibrium conditions, feedback effects, potential emergent properties, and possible regime shifts. Clam garden management influenced nearby habitat and maintained clam populations. Without active management, the system shifts from a productive clam bed to a muddy and sulfidic flat. Communities understood the importance of their management activities. In response to what may be an out-of-equilibrium condition marked by a reduced oyster population, Maryland oyster policy changes reorganized submerged land classifications to create larger no-harvest oyster sanctuaries, reduced bottom for public oyster fisheries, and expanded the potential development of oyster aquaculture (Michaelis et al., in press). As a result, there are more oysters in the water through both sanctuary restoration projects and active oyster aquaculture operations, increasing the ecosystem services provided by oysters. Resource managers hope that these policy changes, paired with better storm water, pollution, and nutrient management at local and watershed levels, may help facilitate an alternative regime with improved water quality, a selfsustaining oyster population, and a healthier Bay-system overall.

Although triggers were not specifically studied in each case study, both may experience similar ones, particularly major weather events that could dramatically impact aquaculture operations, e.g., hurricanes. Major weather events can destroy or alter estuarine habitat and coastal communities through extreme freshwater input and sedimentation, even in a system adapted to extreme variability. Extended weather patterns during a single season can hinder shellfish recruitment and survival, while enhancing predation and disease-related mortality, potentially having a greater impact than harvest pressure (Mackenzie and Tarnowski 2018).

\section{DISCUSSION AND SYNTHESIS}

\section{Favor vs. disfavor}

The presented case studies investigate human-land relationships by illustrating the use of three frameworks: the favor/disfavor dichotomy, RC, and CAS. The results show that the favor/disfavor concept has two dimensions: on the one hand, researchers apply the concept to distinguish between regions suitable and unsuitable for specific uses. On the other hand, the case studies and research on marginality, liminality, and territoriality in anthropology show that favor/disfavor are culturally defined, and the favorability of specific areas often relies on perceptions of individuals and does not always reflect biophysical variables such as temperature or soil quality.

By applying the favor/disfavor concept to different societies, the case studies presented a wide spectrum of human perceptions of landscapes. With respect to the unique temporal and spatial setting, different variables were used in each case study to explain settlement patterns and specific land uses with regard to favor and disfavor. In the German allotment garden study, climate and different levels of available space were used to assign the favor/disfavor categories, though the gardeners themselves do not use these categories. Similarly in Belize, lands currently used by swidden cultivators are viewed favorably by resource users themselves, but are considered unfavorable for this use by outsiders. In another case study, the favor/disfavor concept was applied to the agricultural development in the Black Forest. The Black Forest is seen as a classic region belonging to the disfavorable category because of the low temperature, high precipitation, and poor-quality soils. However, current research indicates that the Black Forest might have been perceived favorably by the early settlers. The case study of Bronze Age land use in southwestern Germany investigated land use in three landscapes, one of which (the Hegau) is supposed to be favorable, while the other two areas are considered to be less suitable for agricultural land use. However, it was pointed out that the perception of these landscapes probably varied with changes in cultural practices and ideas. Thus, while the Hegau is suitable for agriculture and belongs to the favorable category, it might be less suitable for ritual practices than one of the other investigated areas. Both dimensions of the favor/disfavor concept can be seen in the Maryland oyster management as well. Oyster aquaculture leases in the Chesapeake Bay are limited to areas designated as "barren bottom." Though the initial classification of an area as barren may suggest disfavor, continued discussion of best use indicates that these areas are both cultural and ecologically favorable, according to different contemporary perceptions. By using these case studies, the present paper demonstrates that the favor/disfavor concept needs to include cultural aspects, which can be analyzed and compared.

\section{Scale and boundaries}

The studies of the Q'eqchi' Maya swidden agriculture and the allotment gardens in Germany focus on small spatial scales and include historic developments from 1850 onward, and the two other case studies in southwestern Germany cover a greater area, and span of several centuries or millennia. The case studies on aquaculture in the United States both cover a medium spatial scale and have varying time spans, with the clam gardens of the Pacific Northwest Coast dating back 1000-1700 years until the 1930s while the discussion of Maryland oyster management focuses on bottom classification and use in the past century. Despite the different temporal and spatial scales, the criteria of the CAS framework allow a comparison of the different studies.

Boundaries are related to the spatial scale of the systems studied, but include cultural and nongeographic aspects. The physical boundaries varied widely from the household to regional levels, and a community understanding of the boundaries of their system depended who made decisions on resource use and food production and consumption. Both frameworks, RC and CAS, appear adequate for such large variations in space and time and might both allow a cross-scale comparison of case studies that use different aspects and definitions of spatial entities.

\section{Adaptation}

Adaptation processes and decisions in both the Q'eqchi' Maya swidden agriculture and the German allotment garden are made at local, community levels. The users adapt individually to changing conditions, such as droughts, heavy rainfall events or erosion. The success of these adaptations to changing conditions can be measured through the amount and quality of the yield as well as health aspects. Similarly, Kwakwaka'wakw clans managed the clam gardens of the Pacific Northwest Coast by transmitting knowledge orally and via experience. The clans measured their success by health aspects and obtaining a good harvest while simultaneously maintaining the clam population. In the 
Maryland oyster management case study, adaptation happens on the level of the society and individually. Sociopolitical inputs like regulations lead to individual-level adaptations of fishing practices, which may in turn affect other aspects of the system such as target-catch population or other species and habitat. The two archaeological case studies in southwest Germany cannot reconstruct adaptation processes directly because there are only limited artifacts and finds that could verify such a claim. However, long-lasting land use (over several decades and centuries) could point to successful management practices and, thus, indicate adaptation to changing social, cultural, and environmental conditions. Further, the evidence of trade could indicate a swift distribution of ideas and technologies as means for adaptation. The two archaeological case studies benefit from the exchange with the contemporary studies as they provide valuable insights into cultural and social processes and enable new interpretations of archaeological evidence.

\section{Out-of-equilibrium conditions and feedback mechanisms}

Out-of-equilibrium conditions (Lansing 2003) exist in all case studies, even though these conditions have different characteristics. All of the case studies illustrate how human land use can create out-of-equilibrium states in space and time. By using their own energy, humans transformed landscapes in the past and are creating enhanced carrying capacities in diverse regions, from tropical Belize to temperate Germany. This clearly demonstrates that any concept that addresses land use and settlement dynamics needs to account for human agency. The creation of out-of-equilibrium states through human interference also creates feedback for the whole system. The CAS framework enables the comparison of the case studies and includes feedback mechanisms, which are inherent to human actions. The RC framework does not use equilibrium-nonequilibrium as such but includes contingency as a dynamic element to allow for out-ofequilibrium behavior of cultures and the description of cultural turns.

\section{Emergence and regime change}

In CAS, emergent properties such as the self-organization into hierarchies and classes exist, which are contingent and unexpected, so they cannot be explained by focusing on low-level system dynamics. Although the archaeological case studies can only assume emergent properties based on the excavated sites and the artifacts, the observed hierarchies of the contemporary studies might be useful for the interpretation of archaeological finds. The aspect of emergence is especially useful for a better understanding of the favor/disfavor dichotomy. Because emergent properties are not coordinated and cannot be explained by focusing on low-level systems dynamics, these properties could lead to a changed perception of the landscape. Thus, landscapes formerly classified as unfavorable could be reclassified as favorable by the users. CAS also provides insight into how systems can shift into an alternate regime, which might lead to a reclassification of a system from the favorable category into the unfavorable one or vice versa; however, transitions between these states are subject to nonlinear dynamics: movement is not always as easy in both directions. Thus, the CAS framework has the potential to provide new insights for the favor/disfavor concept.

\section{Triggers}

CAS also enables the identification of triggers that could lead to regime shifts. The case studies show that the CAS framework and the identification of possible triggers contribute to a better understanding of the dynamics connected to the favor/disfavor categories. As the case study authors stressed, the definition of favor/disfavor should include cultural aspects, and CAS provides a framework for linking these sociocultural and environmental dynamics. As the case studies indicate, the CAS framework may have limitations concerning archaeological applications due to the availability of data from prehistory which might be better covered by the RC concept. However, considering certain aspects of CAS in archaeological studies can lead to new interpretations of the settlement patterns and the archaeological finds, or it may potentially drive new methods of data collection and analysis.

\section{CONCLUSION}

The results of evaluating the six case studies in light of Complex Adaptive Systems, ResourcesCultures, and the favor-disfavor framework provide new insight on human-landscape relations throughout the Holocene and the Anthropocene. We posit that insights from nonlinear dynamics, new ways of viewing human and natural resources, and complex systems can provide a useful and adaptable framework for doing this in anthropology, archaeology, and soil science. Whereas the RC framework focuses attention on dynamic, culturally defined resources and subjectivity, and the concept of favor-disfavor continues to be used, both RC and CAS reflect insights into the temporal and spatial dynamics of human cultures on the land. We propose that the conceptual triptych of Complex Adaptive Systems, ResourcesCultures, and favor-disfavor is a novel tool to investigate and understand why and how human-land-culture relationships have changed since the end of the Pleistocene, and especially during the Anthropocene. As humans face challenges related to climate disruption, energy use, food production, and cultural change in the coming decades, having a variety of approaches to ask and answer questions is pertinent to broad issues of sustainability, resilience, and adaptability of human societies and environmental systems of which we are a part.

Responses to this article can be read online at: https://www.ecologyandsociety.org/issues/responses. php/12155

\footnotetext{
Acknowledgments:

The authors thank two former graduate students: Heribert Beckmann (Social Anthropology at the University of Tübingen) and Sara Mack (Soil Science at the University of Maryland) for useful contributions to the collaborative field work and to early drafts (HB) that became the foundation for this paper. The authors thank the subject editor and two anonymous reviewers for substantive feedback that helped to improve the manuscript. Any remaining errors in logic or execution remain the responsibility of the authors.

Funds to support this research were provided by the Graduate School, University of Maryland, College Park; the Sustainability Institute at The Ohio State University; the Collaborative Research Center 1070 Resource Cultures (SFB1070) financed by the German Research Foundation (DFG); the National Science Foundation (BCS-1818597), and the Institutional Strategy of the University of Tübingen (Deutsche Forschungsgemeinschaft, ZUK 63 ).
} 


\section{Data Availability:}

The data supporting the findings of this paper were accessed, evaluated, and synthesized from diverse public domain sources cited in each of the six case studies.

\section{LITERATURE CITED}

Balée, W. 2006. The research program of historical ecology. Annual Review of Anthropology 35:75-98. https://doi.org/10.1146/ annurev.anthro.35.081705.123231

Bartelheim, M., R. Hardenberg, T. Knopf, A. K. Scholz, and J. Staecker. 2015. ResourceCultures. A concept for investigating the use of resources in different societies. Pages 33-43 in A. Danielisová and M. Fernández-Götz, editors. Persistent economic ways of living: production, distribution, and consumption in late prehistory and early history. Archaeolingua Main Series Vol. 35. Archaeolingua Alapítvány, Budapest, Hungary.

Bender, B., S. Hamilton, and C. Tilley. 2007. Stone worlds: narrative and reflexivity in landscape archaeology. Left Coast Press, Walnut Creek, California, USA. https://doi. org/10.4324/9781315419657

Biggs, R., T. Blenckner, C. Folke, L. Gordon, A. Norström, M. Nyström, and G. D. Peterson. 2012. Regime shifts. Pages 609-617 in A. Hastings and L. Gross, editors. Encyclopedia of theoretical ecology. University of California Press, Oakland, California, USA.

Bird, R. B. 2015. Disturbance, complexity, scale: new approaches to the study of human-environment interactions. Annual Review of Anthropology 44:241-257. https://doi.org/10.1146/annurevanthro-102214-013946

BKleingG. 1983. Bundeskleingartengesetz. Bundesministerium der Justiz und für Verbraucherschutz, Deutschland, 28.02.1983. BGB1. I S. 210.

Bourke, A. 1984. Impact of climatic fluctuations in European agriculture. Central Europe. Pages 269-296 in H. Flohn and R. Fantechi, editors. The climate of Europe: past, present and future. Natural andman-induced climatic changes: a European perspective. Kluwer, Dordrecht, The Netherlands.

Brown, T., S. Crane, D. O'Sullivan, K. Walsh, and R. Young. 1998. Marginality, multiple estates and environmental change: the case of Lindisfarne. Pages 139-148 in G. Coles and C. M. Mills, editors. Life on the edge. Human settlement andmarginality. Oxbow Books, Oxford, UK. https://doi.org/10.2307/j.ctvh1dhd8.24

Castellani, B. 2013. Map of complexity science. Arts and Science Factory, Cleveland, Ohio, USA. [online] URL: http://www.artsciencefactory.com/complexity-map.html

Coffman, J. A. 2011. On causality in nonlinear complex systems: the developmentalist perspective. Philosophy of Complex Systems (Handbook of the Philosophy of Science) 10:287-309. https://doi. org/10.1016/b978-0-444-52076-0.50010-9

Coombes, P., and K. Barber. 2005. Environmental determinism in Holocene research: causality or coincidence? Area 37:303-311. https://doi.org/10.1111/j.1475-4762.2005.00634.x

Dauber, J., C. Brown, A. L. Fernando, J. Finnan, E. Krasusk, J. Ponitka, D. Styles, D. Thrän, K. J. Van Groenigen, M. Weih, and
R. Zah. 2012. Bioenergy from "surplus" land: environmental and socio-economic implications. BioRisk 7:5-50. https://doi. org/10.3897/biorisk.7.3036

Deur, D., A. Dick, K. Recalma-Clutesi, and N. J. Turner. 2015. Kwakwaka'wakw "clam gardens." Human Ecology 43:201-212. https://doi.org/10.1007/s10745-015-9743-3

Downey, S. S. 2010. Can properties of labor-exchange networks explain the resilience of swidden agriculture? Ecology and Society 15(4):15. https://doi.org/10.5751/es-03686-150415

Downey, S. S. 2015. Q'eqchi' Maya swidden agriculture, settlement history, and colonial enterprise in modern Belize. Ethnohistory 62:751-779. https://doi.org/10.1215/00141801-3135338

Downey, S. S., W. R. Haas, and S. J. Shennan. 2016. European Neolithic societies showed early warning signals of population collapse. Proceedings of the National Academy of Sciences 113:9751-9756. https://doi.org/10.1073/pnas.1602504113

Fisher, L. 2009. The perfect swarm: the science of complexity in everyday life. Basic Books, New York, New York, USA.

Gebhardt, H. 2007. Räumliche kontraste innerhalb BadenWürttembergs. Pages 54-102 in H. Gebhardt, editor. Geographie Baden-Württembergs. Raum, Entwicklung, Regionen. Kohlhammer Stuttgart, Germany.

Gunderson, L. H., and C. S. Holling. 2002. Panarchy: understanding transformations in systems of humans and nature. Island, Washington, D.C., USA.

Hambrecht, G., C. Anderung, S. Brewington, A. Dugmore, R. Edvardsson, F. Feeley, K. Gibbons, R. Harrison, M. Hicks, R. Jackson, et al. 2020. Archaeological sites as distributed long-term observing networks of the past (DONOP). Quaternary International 549:218-226. https://doi.org/10.1016/j.quaint.2018.04.016

Hardenberg, R. 2017a. Dynamic correspondences. ResourceCultures. Pages 25-34 in A. K. Scholz, M. Bartelheim, R. Hardenberg, and J. Staecker, editors. Resource Cultures. Sociocultural dynamics and the use of resources: theories, methods, perspectives. RessourcenKulturen 5. Universität Tübingen, Tübingen, Germany.

Hardenberg, R. 2017b. Introduction. The study of socio-cosmic fields. Pages 7-35 in R. Hardenberg, editor. Approaching ritual economy. Socio-cosmic fields in globalised contexts. RessourcenKulturen 4. Universität Tübingen, Tübingen, Germany.

Hardenberg, R., M. Bartelheim, and J. Staecker. 2017. The resource turn. A sociocultural perspective on resources. Pages 13-23 in A. K. Scholz, M. Bartelheim, R. Hardenberg, and J. Staecker, editors. ResourceCultures. Sociocultural dynamics and the use of resources: theories, methods, perspectives. RessourcenKulturen 5. Universität Tübingen, Tübingen, Germany.

Henkner, J., J. Ahlrichs, S. Downey, M. Fuchs, B. James, A. Junge, T. Knopf, T. Scholten, and P. Kühn. 2018. Archaeopedological analysis of colluvial deposits in favourable and unfavourable areas: reconstruction of land use dynamics in SW Germany. Royal Society Open Science 5:171624. https://doi.org/10.1098/ rsos. 171624 
Henkner, J., J. J. Ahlrichs, S. Downey, M. Fuchs, B. R. James, T. Knopf, T. Scholten, S. Teuber, and P. Kühn. 2017. Archaeopedology and chronostratigraphy of colluvial deposits as a proxy for regional land use history (Baar, southwest Germany). Catena 155:93-113. https://doi.org/10.1016/j.catena.2017.03.005

Holland, J. H. 1995. Hidden order: how adaptation builds complexity. Basic Books, New York, New York, USA.

Holland, J. H. 2014. Complexity: a very short introduction. Oxford University Press, New York, New York, USA. https://doi. org/10.1093/actrade/9780199662548.001.0001

Knopf, T., E. Fischer, L. Kämpf, H. Wagner, L. Wick, F. DupratQualid, H. Floss, T. Frey, A. K. Loy, L. Millet, D. Rius, A. Bräuning, K.-H. Feger, and M. Rösch. 2020. Zur Landnutzungsgeschichte des Südschwarzwalds - archäologische und naturwissenschaftliche Untersuchungen. Fundberichte aus Baden-Württemberg 39:19-101. https://doi.org/10.11588/data/ L00TJW

Krätschmer, M., K. Thode, and C. Vossler-Wolf. 2018. Klöster und ihre Ressourcen - Einleitung. Pages 9-17 in M. Krätschmer, K. Thode, C. Vossler-Wolf, editors. Klöster und Ihre RessourcenRäume und Reformen monastischer Gemeinschaften im Mittelalter. RessourcenKulturen 7. Universität Tübingen, Tübingen, Germany.

Kühn, P., E. Lehndorff, and M. Fuchs. 2017. Lateglacial to Holocene pedogenesis and formation of colluvial deposits in a loess landscape of Central Europe (Wetterau, Germany) Catena 154:118-135. https://doi.org/10.1016/j.catena.2017.02.015

Lansing, J. S. 2003. Complex adaptive systems. Annual Review of Anthropology 32:183-204. https://doi.org/10.1146/annurev. anthro.32.061002.093440

Lansing, J. S. 2006. Perfect order: recognizing complexity in Bali. Princeton Studies in Complexity Vol. 22. Princeton University Press, Princeton, New Jersey, USA. https://doi.org/10.1515/9781400845866

Lansing, J. S. 2007. Priests and programmers: technologies of power in the engineered landscape of Bali. Princeton University Press, Princeton, New Jersey, USA. https://doi.org/10.1515/9781400827633

Lansing, J. S. and S. S. Downey. 2011. Complexity and anthropology. Philosophy of Complex Systems (Handbook of the Philosophy of Science) 10:569-601. https://doi.org/10.1016/ B978-0-444-52076-0.50020-1

Levin, S. A. 1992. The problem of pattern and scale in ecology: The Robert H. MacArthur award lecture. Ecology 73:1943-1967. https://doi.org/10.2307/1941447

Liu, J. 2001. Integrating ecology with human demography, behavior, and socioeconomics: needs and approaches. Ecological Modelling 140:1-8. https://doi.org/10.1016/S0304-3800(01)00265-4

Liu, J., T. Dietz, S. R. Carpenter, C. Folke, M. Alberti, C. L. Redman, S. H. Schneider, E. Ostrom, A. N. Pell, J. Lubchenco, et al. 2007. Coupled human and natural systems. Ambio 36:639-649. https://doi.org/10.1579/0044-7447(2007)36[639:CHANS]2.0.CO;2
Mackenzie Jr, C. L., and M. Tarnowski. 2018. Large shifts in commercial landings of estuarine and bay bivalve mollusks in northeastern United States after 1980 with assessment of the causes. Marine Fisheries Review 80:1-28. https://doi.org/10.7755/ MFR.80.1.1

May, R. M. 1974a. Biological populations with nonoverlapping generations: stable points, stable cycles, and chaos. Science 186:645-647. https://doi.org/10.1126/science.186.4164.645

May, R. M. 1974b. Stability and complexity in model ecosystems. First edition. Princeton University Press, Princeton, New Jersey, USA.

May, R. M. 1976. Simple mathematical models with very complicated dynamics. Nature 261:459-467. https://doi. org/10.1038/261459a0

McGlade, J. 1995. Archaeology and the ecodynamics of humanmodified landscapes. Antiquity 69:113-132. https://doi.org/10.1017/ $\underline{\mathrm{S} 0003598 \times 00064346}$

Michaelis, A. K. 2020. Shellfisheries and cultural ecosystem services: understanding the benefits enabled through work in farmed and wild shellfisheries. Dissertation. University of Maryland, College Park, Maryland, USA.

Michaelis, A. K., W. C. Walton, D. W. Webster, and L. J. Shaffer. 2020. The role of ecosystem services in the decision to grow oysters: a Maryland case study. Aquaculture 529:735-633. https:// doi.org/10.1016/j.aquaculture.2020.735633

Michaelis, A. K., D. W. Webster, and L. J. Shaffer. In press. The practice of everyday oystering: aquaculture as resistance. Journal of Political Ecology.

Miera, J. J. 2020. Ur- und frühgeschichtliche Siedlungsdynamiken zwischen Gunst- und Ungunsträumen in Südwestdeutschland. Landschaftsarchäologische Untersuchungen zur Baar und den angrenzenden Naturräumen des Schwarzwaldes und der Schwäbischen Alb. RessourcenKulturen 10. Tübingen University Press, Tübingen, Germany. https://doi.org/10.15496/publikation-45820

Mitchell, M. 2009. Complexity: a guided tour. Oxford University Press, New York, New York, USA. [online] URL: https://global. oup.com/academic/product/complexity-9780195124415

Moreno, A., K. Ruiz-Mirazo, and X. Barandiaran. 2011. The impact of the paradigm of complexity on the foundational frameworks of biology and cognitive science. Philosophy of Complex Systems (Handbook of the Philosophy of Science) 10:311-333. https://doi.org/10.1016/B978-0-444-52076-0.50011-0

Neuburger, M. 2017. Geographical approaches on territorialities, resources and frontiers. Pages 179-193 in A. K. Scholz, M. Bartelheim, R. Hardenberg, and J. Staecker, editors. Resource Cultures. Sociocultural dynamics and the use of resources: theories, methods, perspectives. RessourcenKulturen 5. Universität Tübingen, Tübingen, Germany.

Nilsen, M. 2014. The working man's green space. University of Virginia Press, Charlottesville, Virginia, USA. 
Odenbaugh, J. 2011. Complex ecological systems. Philosophy of Complex Systems (Handbook of the Philosophy of Science) 10:421-439. https://doi.org/10.1016/B978-0-444-52076-0.50015-8

Pearson, S. M. 2013. Landscape ecology and population dynamics. Pages 488-502 in S. A. Levin, editor. Encyclopedia of biodiversity. Second edition. Academic, Amsterdam, The Netherlands. https://doi.org/10.1016/B978-0-12-384719-5.00417-2

Potschin, M., and O. Bastian. 2004. Landscapes and landscape research in Germany. Belgeo 2-3:265-276. https://doi.org/10.4000/ belgeo. 13688

Scheffer, M., F. Westley, W. A. Brock, and M. Holmgren. 2002. Dynamic interaction of societies and ecosystems: linking theories from ecology, economy, and sociology. Pages 195-239 in L. H. Gunderson and C. S. Holling, editors. Panarchy: understanding transformations in systems of humans and nature. Island, Washington, D.C., USA.

Scherer, S., K. Deckers, J. Dietel, M. Fuchs, J. Henkner, B. Höpfer, A. Junge, E. Kandeler, E. Lehndorff, P. Leinweber, J. Lomax, J. Miera, C. Poll, M. Toffolo, T. Knopf, T. Scholten, and P. Kühn. 2021. What's in a colluvial deposit? Perspectives from archaeopedology. Catena 198:105040. https://doi.org/10.1016/j. catena. 2020.105040

Schmitt, F. 2017. Enclose where the river flows. New investigations on the southern Meseta and the ditched enclosures of Azután (Toledo). Pages 37-57 in M. Bartelheim, P. BuenoRamirez, and M. Kunst, editors. Key resources and socio-cultural developments in the Iberian Chalcolithic. RessourcenKulturen 6. Universität Tübingen, Tübingen, Germany.

Scoones, I. 1999. New ecology and the social sciences: what prospects for a fruitful engagement? Annual Review Anthropology 28:479-507. https://doi.org/10.1146/annurev.anthro.28.1.479

Seidl, A. 2006. Deutsche Agrargeschichte. DLG-Verlags-GmbH, Frankfurt, Germany.

Teuber, S., K. Schmidt, P. Kühn, and T. Scholten. 2019. Engaging with urban green spaces - a comparison of urban and rural allotment gardens in Southwestern Germany. Urban Forestry and Urban Greening 43:126381. https://doi.org/10.1016/j.ufug.2019.126381

Tilley, C. 1994. A phenomenology of landscape: places, paths and monuments. Berg, Oxford, UK.

Wessel, B. M. 2020. Historic preservation for environmental scientists: tools and perspectives to better understand, preserve, and manage the environment. Certificate portfolio project. University of Maryland, College Park, Maryland, USA. [online] URL: https://drum.lib.umd.edu/handle/1903/26029

Wu, J. 2013. Landscape ecology. Pages 179-200 in R. Leemans, editor. Ecological systems. Selected entries from the Encyclopedia of Sustainability Science and Technology. Springer, New York, New York, USA. 


\section{APPENDIX 1 Case Studies}

\section{Maya Swidden Agriculture and German Allotment Gardens}

\section{Q'eqchi' Maya Swidden Agriculture in Belize}

This case study is located in the Toledo District, Belize, where there are 42 Maya villages with populations ranging from 70 to nearly 1,000 (mean $=28$; Toledo Maya Cultural Council 1997). This area is a wet tropical, evergreen lowland forest (Meerman et al. 2003) with mean annual rainfall approaching $4000 \mathrm{~mm}$, mostly occurring during a distinct rainy season from June to December. The earliest contemporary Maya villages in the Toledo District date to the late $19^{\text {th }}$ century (Toledo Maya Cultural Council 1997; Wilk 1997, Downey 2015). Bordering Guatemala to the south and west, and the Caribbean Sea to the east, Toledo has been referred to as "the forgotten district" because it was long neglected by the British colonial government. This contributed to the maintenance of a large proportion of the land in the district as property of the monarch of England up through Independence in 1981, when it became property of the government of Belize. The lack of significant private land may have benefited indigenous populations because it made available forested land for swidden farming with little external regulation or oversight.

Belizean Q'eqchi' cultural norms surrounding household-level land tenure dynamics have been explored ethnographically, and historical and political factors have also been studied (Thompson 1930, Wilk 1997, Downey 2010). Throughout the $20^{\text {th }}$ century, Toledo experienced numerous attempts to develop an export economy, including bananas, oranges, lumber, hogs, and coffee. Over the past 20 years, fair trade cacao (McAnany and Murata 2006), ecotourism (Stinson 2013), illegal rosewood cutting for export to China (Zempel 2014); and most recently, oil exploration (Campbell and Anaya 2008) all impacted the region's economy and cultural transitions. Each phase of natural resource extraction was followed by a period of neglect, and this pattern became a cycle in which the Q'eqchi' had periodic opportunities for wage labor, followed by a return to swidden subsistence (Wilk 1997). And while there is some internal migration from Q'eqchi' villages, often seasonally, for wage labor in agriculture and tourism industries, emigration to the United States is less common from Belize than from other parts of Latin America. The study area has also been the focus of intense legal battles with the Belizean government (Medina 2016), and the villages have in recent years been successful as the courts in Belize and the Caribbean Court of Appeals have upheld petitions for community land rights. This has been a significant legal victory with direct implications on community land management and swidden agriculture.

Labor exchange networks in Toledo exhibit unexpected levels of hierarchy and connectivity without top-down coordination. The Village Chairman and a local leader known as an alcalde are responsible for the overall health of community lands, but they have rarely monitored day-to-day land use activities (Downey 2010). Other social norms and aspects of Q'eqchi' culture and beliefs suggest that local swidden exhibits a conservative ethos. However, the lack of quantitative data specifically supporting this, and poor models for explaining the dynamics of swidden systems generally, have inhibited the development of an understanding of this coupled human-natural system. Ongoing research by Sean Downey and colleagues (2016-2021; NSF BSC \#1553875) is focusing on collecting data and analyzing the coupled dynamics of Q'eqchi' social norms regarding land use 
p. 2

and labor reciprocity. They are also investigating tropical ecosystem dynamics to assess whether local carrying capacities related to maize production are enhanced by human land use activity.

\section{Literature Cited}

Atran, S., D. Medin, N. Ross, E. Lynch, V. Vapnarsky, E. Ucan, and M. Baran. 2002. Folkecology, cultural epidemiology, and the spirit of the commons: A garden experiment in the Maya lowlands, 1991-2001. Current Anthropology 43:421-450.

Balée, W. 2006. The research program of historical ecology. Annual Review of Anthropology 35: 75-98. (doi:10.1146/annurev.anthro.35.081705.123231)

Bird, R. B. 2015. Disturbance, complexity, scale: new approaches to the study of human-environment interactions. Annual Review of Anthropolology 44:241-257. doi:10.1146/annurev-anthro-102214-013946

Campbell, M. S. and S. J. Anaya. 2008. The case of the Maya villages of Belize: reversing the trend of government neglect to secure indigenous land rights. Human Rights Law Review. 8: 377-399.

Chomitz, K. and D. A. Gray. 1995. Roads, lands, markets, and deforestation: a spatial model of land use in Belize. Washington, D.C: World Bank, Policy Research Dept., Environment, Infrastructure, and Agriculture Division.

Downey, S. S. 2010. Can properties of labor-exchange networks explain the resilience of swidden agriculture? Ecology and Society, 15(4).

Downey, S. S. 2015. Swidden, carrying capacity, and colonial enterprise in Southern Belize. Ethnohistory, 62(4).

McAnany, P. A. and S. Murata. 2006. From chocolate pots to Maya gold: Belizean cacao farmers through the ages. In Chocolate in Mesoamerica: A cultural history of cacao. (ed. C. L. McNeil), pp. 429-450. Gainesville, FL, USA: University Press of Florida.

Medina, L. K. 2016. The production of indigenous land rights: judicial decisions across national, regional, and global scales. PoLAR: Political and Legal Anthropology Review 39:139-153.

Meerman, J. C., P. Herrero, and A. Howe. 2003. Rapid ecological assessment: Sarstoon-Temash National Park Toledo District, Belize. Punta Gorda.

Stinson J. 2013. Mother Nature's best kept secret? In Rural livelihoods and the ecotourism/extraction nexus. (eds. B. Bücher and V. Davidov), pp. 88-109. London: Routledge.

Thompson, J. E. S. 1930. Ethnology of the Mayas of southern and central British Honduras. Anthropology series, (Vol. 17). Chicago: Field Museum of Natural History. 
Toledo Maya Cultural Council. 1997. Maya atlas: The struggle to preserve Maya Land in Southern Belize. Berkeley: North Atlantic Books.

Wilk, R. R. 1997. Household ecology: Economic change and domestic life among the Kkekchi Maya in Belize (pp. xxxii, 280). DeKalb: Northern Illinois University Press.

Zempel, C. 2014. Economies of plunder: The case of rosewood extraction and indigenous rights in southern Belize. MPP Professional Paper. St. Paul, Minnesota, USA: Univ. Minnesota.

\section{Urban Allotment Gardening in Southwest Germany}

The case study took place in Baden-Württemberg, southwestern Germany (Teuber et al. 2019), the state known for its capital, Stuttgart, with its global corporations, Mercedes Benz, Porsche, and Bosch. Besides metropolitan Stuttgart, the state has several rural districts where so-called "hidden champions" (Simon 2009) - little known companies that are world leaders in their business sector - provide employment and contribute to the development and growth of the German economy. Although Germany is a highly industrialized country that provides its inhabitants with ample food and many opportunities to spend their free time, gardening is and has been an important activity in the daily life of many Germans. In 2016, 8.4 million of the approximately 82 million inhabitants gardened several times a week, and $17.3 \%$ worked in the garden several times a month (Destatis 2017, Statista 2018). Several of those gardeners do not have access to gardens at their homes, but lease a garden plot from a municipality. Some of these allotments belong to the biggest German allotment association Bundesverband Deutscher Gartenfreunde e.V. (2019) with almost a million members. The allotments leased at rather low rates are located within an enclosed area in which the local representative of the allotment association is responsible for the enforcement of German law, which requires each gardener to grow food on at least one third of their plot (BKleingG 1983). Generally, each gardener tends to a plot of approximately $370 \mathrm{~m}^{2}$, and all plots consist of a small cottage, vegetable patches, flowerbeds and lawn (Bundesverband Deutscher Gartenfreunde e.V., 2019). The overarching allotment association promotes organic gardening management practices. However, each gardener decides individually which practices are used in his/her allotment. In order to investigate these management practices and garden use in German allotment gardens, the ResourceComplex tool was used to identify variables interacting in the individual gardens. Using the variables soil, plants, tools, and knowledge as a starting point, a questionnaire was designed and applied in 6 allotment garden areas located in metropolitan Stuttgart and Villingen-Schwenningen, which is a town in a rural district (Teuber et al. 2019).

Cooperation within the German allotment areas is limited to the maintenance of pathways and the clubhouse or playground, and voluntary networks that individual gardeners establish. This differs from community gardening, as found in many American cities, where the garden is managed cooperatively (Armstrong 2000, Ghose and Pettygrove 2014). Allotment gardens similar in size, history, and management practices to the ones found in Germany exist in England and France (Nilsen 2014); and in Greece, Finland, Estonia, and Poland (Noori and Benson 2016). 
p. 4

Studies in recent years have shown that the gardener's motives for gardening range from food production to leisure activity. Similarly, the allotment gardeners in southwestern Germany value recreational aspects (Teuber et al. 2019). The comparison of metropolitan and rural allotment gardens showed that food production is more important for the latter (Teuber et al. 2019). The gardeners interested in food production retain the socialecological memory of food production, as was first mentioned by Barthel et al. (2010) for the Stockholm allotment gardens. Further differences between the regions are the management practices used by the individual gardeners with new methods being more frequently used in the metropolitan gardens.

Both the urban and rural gardening systems have in common that out-of-equilibrium conditions are created by the gardeners within the boundaries of their plots. First, the management practices of adding compost or manure to the plots creates out-of-equilibrium soil conditions in the metropolitan and rural allotment gardens. Further, both systems have a higher biodiversity than the surrounding areas within the towns and cities where the gardens are located, thus creating another out-of-equilibrium space in the cityscape. As food is cheaply available in supermarkets and in farmers' markets in both German regions, even the time spent in the garden can be considered out-of-equilibrium, if one only considers economic reasoning.

Triggers for the establishment of allotment gardens have been times of crisis, such as industrialization, and the post war periods after World War I and II (Nilsen 2014), which led to the formation of the first association in 1921 (Bundesverband Deutscher Gartenfreunde e.V. 2019). Regime shifts in the gardening community might occur if food production becomes less important within the allotment gardening community. If the allotment gardening law were to change in the future, a regime shift in the gardening community might be possible.

Applying the favor/disfavor dichotomy to the two, surveyed regions indicates that, climatically, Stuttgart is more favored. The soil properties of the allotment gardens in both regions are good, so there is no favor/disfavor dichotomy connected to soils. However, the space required for allotment gardens is less contested in the rural region, as there are fewer conflicts of interest between gardens, infrastructure, industry, and housing, making it favored.

\section{Literature Cited}

Armstrong, D. 2000. A survey of community gardens in upstate New York: Implications for health promotion and community development. Health and Place 6.

Barthel, S., C. Folke, and J. Colding J. 2010. Social-ecological memory in urban gardens - Retaining the capacity for management of ecosystem services. Global Environmental Change 20 (2).

Baumüller, J. 2008. Klimaatlas Region Stuttgart. Stuttgart, Germany: Verband Region Stuttgart.

BkleingG. 1983 Bundeskleingartengesetz. Bundesministerium der Justiz und für Verbraucherschutz, 28.02.1983

Bundesverband Deutscher Gartenfreunde e.V. 2019. Zahlen und Fakten (numbers and facts). http:/www.kleingarten-bund.de/de/portrait/zahlen-und-fakten/. $\quad$ And $\quad \underline{\text { https://www.kleingarten- }}$ bund.de/de/bundesverband/leitbild// Access: 31.01.2019 
p. 5

Destatis. 2017. Bevölkerung (population). Ed. Statistisches Bundeamt Deutschland (German Federal Statistical Office).

DWD (Deutscher Wetterdienst). 2018.

https://www.dwd.de/DE/fachnutzer/freizeitgaertner/3_gartenklima/_node.html. Access: 31.08.2018

Ghose, R. and M. Pettygrove. 2014. Urban Community Gardens as Spaces of Citizenship. Antipode 46 (4).

Keshavarz, N. and S. Bell S. 2016. A history of urban gardens in Europe. In Urban Allotment Gardens in Europe (eds. S. Bell, R. Fox-Kämper, N. Keshavarz, M. Benson, S. Caputo, S. Noori, and A. Voigt), New York, USA: Routledge.

Nilsen, M. 2014. The Working Man's Green Space. Allotment Gardens in England, France, and Germany, 1870-1919. Charlottesville, Virginia, USA: University of Virginia Press.

Noori, S. and M. Benson. 2016. Urban allotment garden. A case for place-making. In Urban Allotment Gardens in Europe (eds. S Bell, R Fox-Kämper, N Keshavarz, M Benson, S Caputo, S Noori, A Voigt), New York: Routledge.

Simon, H. 2009. Hidden champions of the twenty-first century. Success strategies of unknown world market leaders. Heidelberg, Germany: Dordrecht (doi 10.1007/978-0-387-98147-5)

Statista. 2018. Bevölkerung in Deutschland nach Häufigkeit der Gartenarbeit in der Freizeit von 2013 bis 2016 (Population in Germany and the frequency of leisure gardening from 2013 to 2016). https://de.statista.com/statistik/daten/studie/171915/umfrage/haeufigkeit-gartenarbeit-in-der-freizeit/. Access: 31.08.2018

Teuber, S., K. Schmidt, P. Kühn, and T. Scholten. 2019. Engaging with urban green spaces - a comparison of urban and rural allotment gardens in Southwestern Germany. Urban Forestry \& Urban Greening 43:126381.

\section{Black Forest Agriculture and Bronze Age Land Use in Southwest Germany}

\section{Agriculture in the Heights of the Southern Black Forest}

The Black Forest is a mountainous area in southwest Germany covering an area of $6000 \mathrm{~km}^{2}$ and reaching elevations of $1500 \mathrm{~m} .{ }^{1}$ Apart from the valleys, the natural conditions are nearly alpine. Compared to the Rhine River valley to the west, the mean annual temperatures are much lower and the mean annual precipitation is significantly higher. In the southern parts, the main geological substratum comprises crystalline rocks, such as granite and gneiss. The soils are usually described as acidic, poor in nutrients, and containing many stones.

\footnotetext{
${ }^{1}$ This case study is based on fieldwork as part of the research project: Archaeological and natural-scientific investigations on the land use history of the southern Black Forest' financed by the German Research Foundation (DFG).
} 
Historically, the Black Forest is seen as a classic, disfavored region for agriculture. Nevertheless, some authors point to the local existence of soils with a high suitability for agricultural uses (Hädrich and Stahr 2001).

Flint artifacts prove that there was discontinuous land use for hunting or pastoralism in the Paleo-, Meso- and Neolithic times, and pollen analyses show that people changed the forest tree communities for short periods in the Neolithic, Bronze- and Iron Ages; and in Roman times (Rösch 2000, Wagner 2016). From early medieval times onward (Haasis-Berner 2010), archaeological finds and colluvial deposits (Knopf et al. 2012) suggest that humans started to develop and settle the Black Forest systematically.

Since the 1980s, numerous 'stone mounds' of different shapes and sizes have been reported in the area of the town of Titisee-Neustadt. Several thousand of these obviously anthropogenic residues are now documented, mainly on the tops of forested hills and on slopes. Systematic field surveys using LiDAR and mapping were undertaken on two hills near Neustadt, and three mounds were excavated on a hill with an elevation of $1060 \mathrm{~m}$ (Knopf et al. 2016). As a result, the stone mounds can be described as resulting from agriculture. The slopes were terraced, and the excavated mounds consisting of irregular stone piles contained remarkable amounts of charcoal. The spatial distribution of the stone mounds suggests that relatively flat areas on the tops of the hills were left open to practice agriculture or grazing. The overgrown areas were cleared of vegetation (by burning the wood), and the stones were gathered. Radiocarbon dating indicates at least two phases of land use, with one possibly starting in the late $15^{\text {th }}$ century $\mathrm{CE}$, but most probably happening in the $16^{\text {th }}$ century, with a second taking place in the $18^{\text {th }}$ or $19^{\text {th }}$ century. The land use can be imagined as a kind of temporary swidden agriculture with breaks in tillage every five or six years, as is known in other parts of the Black Forest (Reif and Katzmaier 1996, Reif and Katzmair 1997, Henschel and Konold 2008). Intensive land use started with a growing population and the introduction of commons. It is interesting to note, that the land use with stone

mounds largely coincides with the Little Ice Age $\left(15^{\text {th }}-19^{\text {th }}\right.$ century CE), reflecting challenging climatic conditions for food production.

Classically defined, disfavored topographical conditions were turned into more or less useful sites by investing a huge amount of labor. Social, political, and symbolic factors, however, could have contributed to the cultivation of this so called "marginal" land.

\section{Literature Cited}

Haasis-Berner, A. 2010. Das Rätsel vom Titisee - ein Beitrag zur frühmittelalterlichen Besiedlung des Hochschwarzwaldes. Archäologische Nachrichten aus Baden 80/81:45-51.

Hädrich, F. and K. Stahr. 2001. Die Böden des Breisgaus und angrenzender Gebiete. Berichte der Naturforschenden Gesellschaft Freiburg i. Br. 91, p. 108. Freiburg, Germany.

Henschel, K. and W. Konold. 2008. Geschichte der Allmendflächen und Ackerterrassen in der Gemeinde HägEhrsberg (Südschwarzwald). Berichte der Naturforschenden Gesellschaft Freiburg i. Br. 98:143-180 Freiburg, Germany. 
Knopf, T., T. Baum, T. Scholten, and P. Kühn. 2012. Landnutzung im Frühen Mittelalter? Eine archäopedologische Untersuchung im Mittleren Schwarzwald. Archäologisches Korrespondenzblatt 42:123133.

Knopf, T., S. Bosch, L. Kämpf, H. Wagner, E. Fischer, L. Wick, L. Millet, D. Rius, F. Duprat-Qualid, M. Rösch, K. H. Feger, and A. Bräuning. 2016. Archäologische und naturwissenschaftliche Untersuchungen zur Landnutzungsgeschichte des Südschwarzwaldes. Archäologische Ausgrabungen in Baden-Württemberg 2015 Stuttgart 50-55.

Reif, A. and R. Katzmaier. 1996/97. Zur Landnutzungsgeschichte der Allmendweiden von Ibach und Wittenschwand (Südschwarzwald). Berichte der Naturforschenden Gesellschaft Freiburg i. Br. 86/87: 55-98 Freiburg, Germany.

Rösch, M. 2000. Long-term human impact as registered in an upland pollen profile from the southern Black Forest, south-western Germany. Vegetation Hist. Archaeobot. 9:205-218.

Wagner, H. 2011. Römische Besiedlung im Schwarzwald - Von der Auffindung des Undenkbaren. Archäologische Nachrichten aus Baden 82:10-26.

\section{Bronze Age Land Use And Settlement Dynamics In Southwest Germany}

The northern pre-alpine foreland of southwest Germany is a diverse mosaic of geographic landscape units. In an ongoing archaeological-archaeopedological project ${ }^{2}$, we are investigating settlement and land use dynamics in three physically distinct areas during the Bronze Age, especially the Middle Bronze Age $\left(\mathrm{ca} .16^{\text {th }}-13^{\text {th }}\right.$ centuries BCE). Based on physical geographic parameters, e.g. shorter vegetation periods, lower average temperature, and higher precipitation associated with increasing elevation, two of them (Baar and Western Allgäu) appear to be disfavored compared to the third (Hegau).

During the Bronze Age, new technologies, such as the pulled scratch plow and the bronze sickle emerged, along with new species of crops and cattle (Behre 1998, Falkenstein 2009). One of the effects of these developments was a general intensification of land use for food production. Larger fields were kept open for longer periods and tilled more deeply, resulting in drastic soil erosion in many places (Vogt 2014, Dreibrodt et al. 2010, Henkner et al. 2017). At the same time, the remaining forests increasingly became open, oak-dominated forests used for grazing (Rösch 2013; Rösch et al. 2014). Another major characteristic of this period was the increasing importance of interregional exchange of copper, tin, amber, salt and other resources, as demands for steady supplies grew along with technological and cultural developments (Woltermann 2014, Kristiansen and Suchowska-Ducke 2015).

\footnotetext{
2 "Favour - Disfavour? Development of resources in marginal areas" under the supervision of Prof. Dr. Scholten, Prof. Dr. Knopf and Dr. P. Kuehn in the Collaborative Research Center SFB 1070 RESOURCECULTURES, financed by the German Research Foundation (DFG).
} 
The spatial distribution of archaeological sites seems to attest to the importance of such exchanges: many sites from the later Early and Middle Bronze Ages are situated on hills or outcrops, often referred to as "hilltop settlements," along larger river valleys. Their actual function as permanent settlements is often debatable, as is their exact age, but it seems clear that they were in some way involved in the structuring of exchange networks (Köninger and Schöbel 2010). During the transition towards the Middle Bronze Age, changes occurred in the distribution of settlement types. Earlier (ca. $18^{\text {th }}$ and $17^{\text {th }}$ centuries BCE), "pile dwellings" on the lakeshores had become the predominant settlement type. Some of these were quite heavily fortified, which seems to identify them as junctions or nodal points within the interregional exchange network (Köninger and Schöbel 2010). During the Middle Bronze Age, the lakeshores were quite suddenly and almost entirely abandoned. This was usually related to a phase of deteriorating climate and rising water levels, which lasted for several centuries and prevented resettlement of the lakeshores until the $11^{\text {th }}$ century BCE (Menotti 2001; Magny 2004). At the same time, the number of inland settlements (around the hilltops) multiplied. This is most evident in the Hegau next to Lake Constance and might, therefore, be seen as a direct reaction to rising water levels. However, it can also be seen in the allegedly more disfavored landscape units of the Baar and Western Allgäu further inland. Climate change and the resulting disappearance of the ephemeral lakes alone cannot explain why settlement of these remote regions should have intensified. Instead, other factors must have played a role in this dynamic, perhaps adding to the hardships already imposed by climate change. In a cultural system that increasingly focused on long-distance exchange networks, the connective topography of certain regions could obviously have become a key resource: in the Baar, the great Danube River springs, and it also connects to the northern part of southwest Germany, while the western Allgäu comprises the main watershed between the Danube and the Rhine River systems, connecting both.

\section{Literature Cited}

Behre, K-E. 1998. Landwirtschaftliche Entwicklungslinien und die Veränderungen der Kulturlandschaft in der Bronzezeit Europas. In Mensch und Umwelt in der Bronzezeit Europas - Man and Environment in the European Bronze Age (ed. Haensel B), pp. 91-109. Kiel, Germany: Oetker Voges.

Dreibrodt, S., C. Lubos, B. Terhorst, B. Damm, and H. R. Bork. 2010. Historical soil erosion by water in Germany: Scales and archives, chronology, research perspectives. Quaternary International 222:80-95.

Falkenstein, F. 2009. Zur Subsistenzwirtschaft der Bronzezeit in Mittel- und Südosteuropa1. In Die wirtschaftlichen Grundlagen der Bronzezeit Europas - The economic foundations oft the European Bronze Age (eds. M Bartelheim, M Stäuble) Forschungen zur Archäometrie und Altertumswissenschaft 4:47-176.

Henkner, J., J. J. Ahlrichs, S. S. Downey, M. Fuchs, B. R. James, T. Knopf, T. Scholten, S. Teuber, and P. Kühn P. 2017. Archaeopedology and chronostratigraphy of colluvial deposits as a proxy for regional land use history (Baar, southwest Germany). Catena 155: 93-113.

Köninger, J. and G. Schöbel. 2010. Bronzezeitliche Fundstellen zwischen Bodensee und Oberschwaben. In Vernetzungen: Aspekte siedlungsarchäologischer Forschungen (eds. I Matuschik, C Strahm), pp.385-435. Freiburg: Lavori. 
Kristiansen, K., and P. Suchowska-Ducke. 2015. Connected histories: the dynamics of Bronze Age interaction and trade 1500 - 1100 BC. Proceedings of the Prehistory Society 81:361-392.

Magny, M. 2004. The contribution of palaeoclimatology to the lake-dwellings. In Living on the lake in prehistoric Europe -- 150 years of lake-dwelling research (ed. F Menotti), pp. 132-143. London: Routledge.

Menotti, F. 2001. The missing period - Middle Bronze Age lake-dwellings in the Alps. BAR Intern. Archaeol. Rep. (BAR no. S986). Oxford: BAR Publ.

Rösch, M. 2013. Land use and food production in Central Europe from the Neolithic to the Medieval period: change of landscape, soils and agricultural systems according to archaeobotanical data. In: Economic archaeology: from structure to performance in European archaeology (eds. T Kerig, A Zimmermann) pp. 109127. Bonn: Verlag Dr. Rudolf Habelt GmbH.

Rösch, M., A. Kleinmann, J. Lechterbeck, and L. Wick. 2014. Botanical off-site and on-site data as indicators of different land use systems: a discussion with examples from Southwest Germany. Vegetation History and Archaeobotany. 23:121-133(suppl. 1) (doi 10.1007/s00334-014-0437-3)

Vogt, R. 2014. Kolluvien als Archive für anthropogen ausgelöste Landschaftsveränderungen an Beispielen aus der westlichen Bodenseeregion. Stuttgart, Germany: Thesis.

Woltermann, G. 2014. Bernsteinschmuckproduktion in der Hügelgräberzeit. In Ressourcen und Rohstoffe in der Bronzezeit. Nutzung - Distribution - Kontrolle Beiträge zur Sitzung der Arbeitsgemeinschaft Bronzezeit auf der Jahrestagung des Mittel. und Ostdeutschen Verandes fr Altertumsforschung in Brandenburg an der Havel, Arbeitsber. Bodendenkmalpfl. 26:74-86. 


\section{Coastal Aquaculture}

\section{Clam Gardens on the Pacific Northwest Coast}

Beyond the soils and landscapes of upland environments, human cultures have had complex relationships with aquatic resources and the boundary between land and sea throughout the Holocene, for example, through the creation of clam gardens. Over the past century or so, the development of the aquatic sciences and soil sciences as independent disciplines has largely prevented the application of soil and landscape concepts in aquatic environments. However, collaborations over the past two decades have begun to bridge these fields by adapting soil and land management practices and perspectives to subaqueous landscapes (Kristensen and Rabenhorst 2015). This may ultimately bring modern territorialities of aquatic resources more in line with those of prehistoric Holocene peoples, at least some of whom actively managed "clam gardens" as complex adaptive systems long before the advent of modern aquaculture.

On the North American Pacific Northwest Coast, tribes of the Kwakwaka'wakw Nation built clam gardens by rolling cobbles and boulders from existing clam beds, piling them in bulwarks near the low-tide line. This caused sediment to accumulate on the shoreward side of the bulwark, building a terrace that was exposed at low tide and covered by shallow water at high tide. This allowed the expansion of optimal soils for clam beds near settlements. Clam gardens were maintained by continuing to move exposed rocks and other debris to increase the available sandy habitat for clams, by practicing selective harvesting to maintain clam populations, and by regularly disturbing the soil using digging sticks to improve soil conditions.

The Kwakwaka'wakw had a basic, useful soil taxonomy, calling black and rotten-egg smelling soil kwen'xlis, which would produce unpalatable clams called ya'yeks (Deur et al. 2015). These soils have only recently been recognized as "monosulfidic materials" by modern soil taxonomists (Wessel and Rabenhorst 2017). The Kwakwaka'wakw would dig these soils to aerate them and to allow the silt and clay to be carried away by the tide, preventing the formation of kwen'xlis and maintaining sandy clam habitat.

Individual clans claimed clam gardens and maintained them for generations, with a belief that the clams were related to humans and would make themselves available for harvest if cared for. Some members of these tribes still harvest clams at these gardens, though no longer build or actively maintain them for artificially high carrying capacities for clam communities (Deur et al. 2015). Clam gardens originated at least as early as 10001700 years ago on Quadra Island in British Columbia, Canada, indicated by optical luminescence dating of core samples (Neudorf et al. 2017). Clam gardens improved food security and built more resilient coupled humanocean systems, improving marginal environments with a territoriality that identified the value in cultivating this land (Jackley et al. 2016).

Achieving this type of territoriality, which allows the active management and improvement of marginal, submerged land for aquaculture, has been a challenging task in many parts of the modern world due to the public trust doctrine, which dates to the Roman Empire and was subsequently adopted by English common law and modern nation states. Under this doctrine, submerged lands are held by the government for public use, particularly to preserve the navigational use of the waterways. Many possible submerged land uses involving private property rights are generally prohibited by this doctrine (Rindner 2011). This may actually decrease the 
resilience of modern settlements by preventing the adoption of aquacultural practices that helped to maintain prehistoric peoples for centuries. Nonetheless, recent legislative changes in some parts of the world are expressing a territoriality that values private management of submerged lands, enabling their creative use as community resources (Beck et al. 2004).

\section{Literature Cited}

Beck, M. W., T. D. Marsh, S. E. Reisewitz, and M. L. Bortman. 2004. New Tools for marine conservation: the leasing and ownership of submerged lands. Conservation. Biology. 18:1214-1223.

Deur, D., A. Dick, K. Recalma-Clutesi, and N. J. Turner. 2015. Kwakwaka'wakw "Clam Gardens". Human Ecology 43:201-212.

Jackley, J., L. Gardner, A. F. Djunaedi, and A. K. Salomon. 2016. Ancient clam gardens, traditional management portfolios, and the resilience of coupled human-ocean systems. Ecology and. Society 21(4).

Kristensen, E., and M. C. Rabenhorst. 2015. Do marine rooted plants grow in sediment or soil? A critical appraisal on definitions, methodology and communication. Earth-Science Review 145:1-8.

Neudorf, C. M., N. Smith, D. Lepofsky, G. Toniello, O. B. Lian. 2017. Between a rock and a soft place: Using optical ages to date ancient clam gardens on the Pacific Northwest. Plos One 12(2).

Rindner, L. 2011. Forcing adaptation through the Rivers and Harbors Act. Ecological Law Quarterly 38:341368.

Wessel, B. M., and M. C. Rabenhorst. 2017. Identification of sulfidic materials in the Rhode River subestuary of Chesapeake Bay. Geoderma 308:215-225. (Supplement C)

Maryland Oyster Management and Barren Bottom (Chesapeake Bay, USA)

In the Maryland portion of the Chesapeake Bay (United States), classification of what may be considered marginal or disfavored submerged land underscores the dynamic and subjective nature of favor and disfavor. Maryland's eastern oyster (Crassostrea virginica) population has historically been managed utilizing the designation of 'barren bottom' (Kennedy and Breisch 1983, MD DNR, 1997). This terrain ranges from soft, easily penetrable muddy sediment, to hard scoured sand, to less commonly, but still possible, oyster shell left as remnants of an earlier, much larger oyster population. Though the content of 'barren bottom' varies, the designation is typified by a general absence of living oysters (Kennedy and Breisch 1983). Recognized as disfavored to some, this estuarine bay bottom is highly valued by certain groups and holds higher import than what the label of 'barren bottom' suggests. 
While unlikely habitat for large numbers of wild oysters, barren bottom hosts several species of clam (Mercenaria mercenaria, Mya arenaria, and Tagelus plebius) that, in addition to filling an ecological role, provide a source of income for commercial clammers (Baker and Mann 1991, Homer et al. 2011, MD DNR, 2018). Sand and mud sites that typify barren bottom also provide nursery habitat, foraging grounds, and overwintering locations for blue crabs (Callinectes sapidus), another commercially important species (Dittel et al. 1995, Seitz et al. 2001, Seitz et al. 2003). Barren bottom exclusively is the area available for private leasing for oyster aquaculture. Oyster aquaculture, the farming or cultivation of oysters, has existed in the Chesapeake for several centuries, but was a limited industry in Maryland until legislative changes in 2009-2010 (MD DNR 2010, Webster and Merritt 1988). Even so, over a century of regulatory changes center upon barren bottom, highlighting the irony that what is deemed disfavored terrain continues to be socially, politically, and ecologically valuable and favored.

Conflicting claims to barren bottom are further complicated when considering the changes in the environmental and cultural aspects of the Chesapeake Bay as a complex adaptive system. Maryland's oyster population is a small fraction of its historic size due to a combination of inputs, including habitat loss, overharvest, oyster disease, and eutrophication; all exacerbated by warming water temperatures (Fulford et al. 2007, Kennedy and Breisch 1983, Wilberg et al. 2011, Mackenzie and Tarnowski 2018). As ecosystem engineers and providers of numerous ecosystem services, oysters play a large role in their systems, and their population decline contributed to the Bay's current regime and recurring dead zones (Dybas 2005, Coen et al. 2007, Diaz and Rosenberg 2007, Grabowski and Peterson 2007, Dumbauld et al. 2009,). Accordingly, a dramatic increase in the number of oysters - through both restoration projects and oyster aquaculture - is viewed by many as the potential key to a healthy Bay, though that remains a lofty goal (Fulford et al. 2007, Mann and Powell 2007, Beck et al. 2011, Bricker et al. 2017). Paired with other actions, oyster restoration efforts could lead to a new regime and state of the Bay, however, the socioeconomic implications of such a shift may not be welcomed by all. As rights to submerged land continue to change, questions of best use and equity are raised. Through ongoing work to understand participation in oyster aquaculture in Maryland, the impact of expanded no-harvest sanctuaries and privatized aquaculture leasing on local livelihoods is being investigated (2016-2018 Maryland Sea Grant SA75281600D; 2018-2020 NSF BCS1822266).

\section{Literature Cited}

Baker, P. K., and R. Mann. 1991. Soft shell clam. In Habitat Requirements for Chesapeake Bay Living Resources (eds. S. Funderburk, J. A. Mihursky, S. J, Jordan, and D. Riley), Annapolis, Maryland, USA: U.S. Fish and Wildlife Service.

Beck, M. W., R. D. Brumbaugh, L. Airoldi, A. Carranza, L. D. Coen, C. Crawford, et al. 2011. Oyster reefs at risk and recommendations for conservation, restoration, and management. Bioscience 61:107-116.

Bricker, S.B., J. G. Ferreira, C. Zhu, J. M. Rose, E. Galimany, G. Wikfors, et al. 2017. The role of shellfish aquaculture in reduction of eutrophication in an urban estuary. Environmental. Science and Technology 52: 173183. 
Coen, L. D., R. D. Brumbaugh, D. Bushek, R. Grizzle, M. W. Luckenbach, M. H. Posey, et al. 2007. Ecosystem services related to oyster restoration. Marine Ecology Progress Series 341: 303-307.

Diaz, R. J., and R. Rosenberg. 2008. Spreading dead zones and consequences for marine ecosystems. Science 321:926-929.

Dittel, A., A. H. Hines, G. Ruiz, and K. K. Ruffin. 1995. Effects of shallow water refuge on behavior and density dependent mortality of juvenile blue crabs in Chesapeake Bay. Bulletin of Marine Science 57:902-916.

Dumbauld, B. R., and L.M. McCoy. 2015. Effect of oyster aquaculture on seagrass Zostera marina at the estuarine landscape scale in Willapa Bay, Washington (USA). Aquaculture Environment Interactions, 7:29-47.

Dumbauld, B. R., J. L. Ruesink, and S. S. Rumrill. 2009. The ecological role of bivalve shellfish aquaculture in the estuarine environment: A review with application to oyster and clam culture in West Coast (USA) estuaries. Aquaculture 290:196-223.

Dybas, C. L. 2005. Dead zones spreading in world oceans. AIBS Bulletin 55:552-557.

Ferreira, J. G. and S. B. Bricker. 2016. Goods and services of extensive aquaculture: Shellfish culture and nutrient trading. Aquaculture International. 24:803-825.

Fulford, R. S., D. L. Breitburg, R. I. Newell, W. M. Kemp, M. Luckenbach. 2007. Effects of oyster population restoration strategies on phytoplankton biomass in Chesapeake Bay: A flexible modeling approach. Marine Ecology Progress Series 336:43-61.

Grabowski, J. H. and C. H. Peterson. 2007. Restoring oyster reefs to recover ecosystem services. Ecosystem Engineers: Plants to Protists 4:281-298.

Homer, M., C. F. Dungan, M. Tarnowski. 2011. Assessment of Chesapeake Bay commercial softshell clams, Mya arenaria and Tagelus plebeius, with emphasis on abundance and disease status. Completion Rep. to NOAA Chesapeake Bay Fishery Sciences Progress NA07NMF4570326.

Kennedy, V. S., and L. L. Breisch. 1983. Sixteen decades of political management of the oyster fishery in Maryland's Chesapeake Bay. Journal of. Environmental Management 16:153-171.

Mackenzie, C. L. and M. L. Tarnowski. 2018. Large shifts in commercial landings of estuarine and bay bivalve mollusks in northeastern United States after 1980 with assessment of the causes. Marine Fisheries Review 80:1-28.

Mann, R. and E. N. Powell. 2007. Why oyster restoration goals in the Chesapeake Bay are not and probably cannot be achieved. Journal of. Shellfish Research 26:905-917. 
[MD DNR] Maryland Department of Natural Resources. 1997. Maryland's Historic Oyster Bottom: A Geographic Representation of the Traditional Named Oyster Bars. Maryland Department of Natural Resources Fisheries Service Cooperative Oxford Laboratory. Accessed March 20, 2018 from:

http://dnr.maryland.gov/fisheries/Documents/maryland_historic_oyster_bottom.pdf

[MD DNR] Maryland Department of Natural Resources. 2010. Oyster Packages September 2010. Maryland Department of Natural Resources Fisheries Service. Maryland Register 37 (14), 943. Accessed March 30, 2018 from: http://dnr.maryland.gov/fisheries/Documents/Oyster\%20Packages\%20September\%202010.pdf

[MD DNR] Maryland Department of Natural Resources. 2018. Commercial clams in Maryland's Chesapeake Bay. Maryland Department of Natural Resources Fisheries Service. Accessed March 30, 2018 from: http://dnr.maryland.gov/fisheries/Pages/shellfish-monitoring/clams.aspx.

Orth, R. J., W. C. Dennison, J. S. Lefcheck, C. Gurbisz, M. Hannam, J. Keisman, J. B. Landry, K. A. Moore, R. R. Murphy, and C. J. Patrick. 2017. Submersed aquatic vegetation in Chesapeake Bay: sentinel species in a changing world. Bioscience 67:698-712.

Seitz, R., R. Lipcius, W. Stockhausen, and M. Montane. 2001. Efficacy of blue crab spawning sanctuaries in Chesapeake Bay. In Spatial Processes and Management of Marine Populations (eds. G.H. Kruse, N. Bez, A. Booth, et al.), pp. 607-626. Anchorage, Alaska, USA: Univ. Alaska Sea Grant Coll.

Seitz, R.D., R. N. Lipcius, W. T. Stockhausen, K. A. Delano, M. S. Seebo, and P. D. Gerdes. 2003. Potential bottom-up control of blue crab distribution at various spatial scales. Bulletin of Marine Science 72:471-490.

Webster, D. and D. Merritt. 1988. Stabilizing oyster ground. College Park, Maryland, USA: Maryland Sea Grant Extension Program. UM-SG-MAP-88-04.

Wilberg, M.J., M. E. Livings, J. S. Barkman, B. T. Morris, and J. M. Robinson. 2011. Overfishing, disease, habitat loss, and potential extirpation of oysters in upper Chesapeake Bay. Marine Ecology. Progress Series 436:131-144. 


\section{Table A1.1 Summary of Case Study Data Evaluated Under the Rubric of Complex Adaptive Systems Criteria}

\begin{tabular}{|c|c|c|c|c|c|c|}
\hline Criteria & $\begin{array}{l}\text { Q'eqchi' Maya } \\
\text { Swidden } \\
\text { Agriculture } \\
\text { (Belize) }\end{array}$ & $\begin{array}{l}\text { Urban } \\
\text { Gardening in } \\
\text { SW-Germany }\end{array}$ & $\begin{array}{l}\text { Agriculture in the } \\
\text { Black Forest }\end{array}$ & $\begin{array}{l}\text { Bronze Age } \\
\text { land use in SW- } \\
\text { Germany }\end{array}$ & $\begin{array}{l}\text { Clam Gardens } \\
\text { on the Pacific } \\
\text { Northwest } \\
\text { Coast (Canada) }\end{array}$ & $\begin{array}{l}\text { Maryland Oyster Management } \\
\text { (Chesapeake Bay, U.S.) }\end{array}$ \\
\hline $\begin{array}{l}\text { Nature of land use } \\
\text { investigated } \\
\text { (contemporary or } \\
\text { archaeological) }\end{array}$ & Contemporary & Contemporary & Archaeological & Archaeological & Archaeological & Contemporary \\
\hline $\begin{array}{l}\text { Favorability/ } \\
\text { unfavorability } \\
\text { (defined } \\
\text { exogenously, } \\
\text { endogenously, or } \\
\text { both) }\end{array}$ & $\begin{array}{l}\text { Defined both } \\
\text { exogenously } \\
\text { and } \\
\text { endogenously: } \\
\text { unfavorable for } \\
\text { swidden } \\
\text { cultivation } \\
\text { (Atran 2002) } \\
\text { due to high } \\
\text { annual } \\
\text { precipitation } \\
\text { and soil } \\
\text { leaching; } \\
\text { favorability has } \\
\text { previously been } \\
\text { defined } \\
\text { historically and } \\
\text { relatively. } \\
\text { Q'eqchi' } \\
\text { communities } \\
\text { tend to view } \\
\text { land use more } \\
\text { favorably }\end{array}$ & $\begin{array}{l}\text { Defined } \\
\text { exogenously: } \\
\text { Stuttgart has a } \\
\text { more } \\
\text { favorable } \\
\text { climate than } \\
\text { does rural } \\
\text { Villingen- } \\
\text { Schwenningen } \\
\text { (Baumüller J } \\
\text { 2008; DWD } \\
\text { 2018); no } \\
\text { difference in } \\
\text { soils (Teuber } \\
\text { et al. 2019); } \\
\text { spatially, the } \\
\text { rural region is } \\
\text { favorable due } \\
\text { to less } \\
\text { contested } \\
\text { spaces }\end{array}$ & $\begin{array}{l}\text { Defined } \\
\text { exogenously: } \\
\text { Black Forest as a } \\
\text { classic } \\
\text { unfavorable } \\
\text { region (soil, } \\
\text { temperature, } \\
\text { precipitation); } \\
\text { some resources } \\
\text { (wood, metal } \\
\text { ores, control of } \\
\text { trade etc.) } \\
\text { important, } \\
\text { therefore } \\
\text { favorable } \\
\text { aspects; } \\
\text { depending on } \\
\text { time, scale, and } \\
\text { specific culturally } \\
\text { determined } \\
\text { resource use }\end{array}$ & $\begin{array}{l}\text { Defined } \\
\text { exogenously: } \\
\text { considering the } \\
\text { relative } \\
\text { suitability of } \\
\text { areas for } \\
\text { Bronze Age } \\
\text { agriculture, } \\
\text { emphasis on } \\
\text { social/immateri } \\
\text { al needs } \\
\text { (including } \\
\text { burial/ritual } \\
\text { sites, trading } \\
\text { routes etc.) in } \\
\text { the assessment } \\
\text { of a } \\
\text { landscape's } \\
\text { favorability. }\end{array}$ & $\begin{array}{l}\text { Defined } \\
\text { exogenously } \\
\text { and } \\
\text { endogenously: } \\
\text { First Nations } \\
\text { that practiced } \\
\text { clam garden } \\
\text { aquaculture } \\
\text { saw these } \\
\text { areas as } \\
\text { favorable and } \\
\text { able to be } \\
\text { improved; } \\
\text { most modern } \\
\text { societies view } \\
\text { these areas as } \\
\text { unfavorable } \\
\text { due to } \\
\text { legal/cultural } \\
\text { traditions } \\
\text { inherited from } \\
\text { Antiquity. }\end{array}$ & $\begin{array}{l}\text { Defined exogenously and } \\
\text { endogenously: oyster leases are } \\
\text { limited to areas designated as } \\
\text { 'barren bottom', a classification } \\
\text { that originated with the Yates } \\
\text { Survey in } 1906 \text { (Kennedy \& } \\
\text { Breisch, 1983) and typified by a } \\
\text { lack of oysters, thus, seemingly } \\
\text { unfavourable; today a contested } \\
\text { space for multiple public fisheries, } \\
\text { private aquaculture, and even } \\
\text { nearby landowners }\end{array}$ \\
\hline $\begin{array}{l}\text { Scale of the } \\
\text { investigated system } \\
\text { in space and time } \\
\text { (small: } \\
\text { local/months to } \\
\text { years; medium: } \\
\text { regional/years to } \\
\text { centuries; large: } \\
\text { geographic } \\
\text { units/decades to } \\
\text { millennia) }\end{array}$ & $\begin{array}{l}\text { Small: } \\
\text { approximately } \\
12 \text { villages, } 700 \\
\text { people, } 77 \mathrm{~km}^{2} \text {, } \\
\text { and } 150 \mathrm{yr} \\
\text { history. }\end{array}$ & $\begin{array}{l}\text { Small: } 2 \\
\text { towns, } 6 \\
\text { garden } \\
\text { associations, } \\
167 \\
\text { gardeners, } 2 \\
\text { yr } \\
\text { investigation, } \\
\text { history of } \\
\text { garden } \\
\text { associations } \\
\text { dating back to } \\
\text { the World } \\
\text { Wars }\end{array}$ & $\begin{array}{l}\text { Medium: Field } \\
\text { work in ca. } 100 \\
\mathrm{~km}^{2} \text { around one } \\
\text { town (Neustadt) } \\
\text { and probably a } \\
\text { dozen farms, } \\
\text { focus in time ca. } \\
400 \text { yrs (1500- } \\
1900 \text { CE), in Early } \\
\text { Modern times, } \\
\sim 1000 \text { people }\end{array}$ & $\begin{array}{l}\text { Large: three } \\
\text { levels of spatial } \\
\text { scale: (i) } \\
\text { individual } \\
\text { settlements } \\
\text { with their daily } \\
\text { activity zones } \\
\text { of several km², } \\
\text { (ii) local } \\
\text { networks of } \\
\text { several } \\
\text { (cooperating?) } \\
\text { settlements, } \\
\text { spread over a } \\
\text { few dozen km², } \\
\text { and (iii) } \\
\text { regional } \\
\text { networks of }\end{array}$ & $\begin{array}{l}\text { Medium: } \\
\text { largely } \\
\text { restricted to } \\
\text { the Pacific } \\
\text { Northwest } \\
\text { Coast, } \\
\text { particularly in } \\
\text { the Broughton } \\
\text { Archipelago } \\
\text { and islands } \\
\text { between } \\
\text { Vancouver } \\
\text { Island and the } \\
\text { continent } \\
\text { (Deur et al. } \\
\text { 2015), } \\
\text { managed by } \\
\text { clans from }\end{array}$ & $\begin{array}{l}\text { Medium: the Chesapeake Bay } \\
\text { estuary spans } 11,600 \mathrm{~km}^{2} ; \\
\text { Maryland oyster management } \\
\text { includes several centuries of public } \\
\text { and private (aquaculture) fisheries } \\
\text { in the northern portion of the Bay; } \\
\text { fisheries vary in size and now } \\
\text { include } 3,000 \text { commercial } \\
\text { watermen and fewer than } 500 \\
\text { individuals licensed to harvest } \\
\text { aquaculture oysters; } 69 \text { individuals } \\
\text { involved in Maryland fisheries } \\
\text { were interviewed, participant } \\
\text { observation was conducted with } \\
\text { over } 100 \text {. }\end{array}$ \\
\hline
\end{tabular}




\begin{tabular}{|c|c|c|c|c|c|c|}
\hline & & & & $\begin{array}{l}\text { settlements in } \\
\text { larger } \\
\text { landscape units } \\
\text { of several } \\
\text { hundred km²; } \\
\text { temporal } \\
\text { frame: Bronze } \\
\text { Age ( } 2150 \text { - } \\
800 \text { BCE) with } \\
\text { emphasis on } \\
\text { the Middle } \\
\text { Bronze Age ( } \\
1650 \text { - } 1250 \\
\text { BCE). }\end{array}$ & $\begin{array}{l}1000-1700 \\
\text { years ago to } \\
\sim 1930 \mathrm{~s}\end{array}$ & \\
\hline $\begin{array}{l}\text { System boundaries } \\
\text { (clearly defined and } \\
\text { understood or } \\
\text { poorly defined) }\end{array}$ & $\begin{array}{l}\text { Clearly defined: } \\
\text { household } \\
\text { organization } \\
\text { and intra- } \\
\text { village ties are } \\
\text { very important; } \\
\text { regional and } \\
\text { global } \\
\text { connections } \\
\text { also important, } \\
\text { particularly due } \\
\text { to government, } \\
\text { NGOs, } \\
\text { churches, and } \\
\text { international } \\
\text { development } \\
\text { efforts; the } \\
\text { region is being } \\
\text { affected by } \\
\text { climate change } \\
\text {-- precipitation } \\
\text { is becoming } \\
\text { more difficult } \\
\text { to predict } \\
\text { which is } \\
\text { impacting crops }\end{array}$ & $\begin{array}{l}\text { Clearly } \\
\text { defined: } \\
\text { Nested } \\
\text { system of (i) } \\
\text { the individual } \\
\text { garden } \\
\text { managed by a } \\
\text { gardener(s); } \\
\text { (ii) the } \\
\text { gardening } \\
\text { association } \\
\text { each garden } \\
\text { belongs to; } \\
\text { (iii) the } \\
\text { overarching } \\
\text { German } \\
\text { allotment } \\
\text { garden } \\
\text { association } \\
\text { which issues } \\
\text { rules and } \\
\text { regulations } \\
\text { according to } \\
\text { German law; } \\
\text { each garden } \\
\text { as an intricate } \\
\text { system of } \\
\text { humans and } \\
\text { nature }\end{array}$ & $\begin{array}{l}\text { Clearly defined: } \\
\text { household and } \\
\text { farming } \\
\text { organization for } \\
\text { single farms, } \\
\text { network with } \\
\text { other farms and } \\
\text { relation to town, } \\
\text { probably clearly } \\
\text { defined within } \\
\text { rules and norms } \\
\text { how to live and } \\
\text { farm; religious } \\
\text { boundaries } \\
\text { (Christianity); } \\
\text { physical } \\
\text { boundaries by } \\
\text { topography and } \\
\text { climate }\end{array}$ & $\begin{array}{l}\text { Poorly defined: } \\
\text { system } \\
\text { boundaries are } \\
\text { based on } \\
\text { modern } \\
\text { assumptions } \\
\text { due to the lack } \\
\text { of specific } \\
\text { historical data }\end{array}$ & $\begin{array}{l}\text { Clearly } \\
\text { defined: (i) } \\
\text { individual clam } \\
\text { gardens, } \\
\text { defined by a } \\
\text { bulwark at the } \\
\text { seaward side } \\
\text { and the shore } \\
\text { on the } \\
\text { landward side, } \\
\text { and bounded } \\
\text { by water depth } \\
\text { (ii) } \\
\text { organizational } \\
\text { and } \\
\text { archaeological, } \\
\text { with a single } \\
\text { clan generally } \\
\text { maintaining } \\
\text { one garden or } \\
\text { area of } \\
\text { gardens, (iii) } \\
\text { contemporary, } \\
\text { where these } \\
\text { are maintained } \\
\text { and well } \\
\text { delineated as } \\
\text { public trust } \\
\text { resources that } \\
\text { the public can } \\
\text { use for } \\
\text { recreational } \\
\text { clamming } \\
\text { during the } \\
\text { correct } \\
\text { seasons }\end{array}$ & $\begin{array}{l}\text { Clearly defined: the Chesapeake } \\
\text { Bay is an extremely dynamic } \\
\text { estuary experiencing wide-ranging } \\
\text { salinities ( } 0.5 \text { ppt/freshwater in its } \\
\text { upper tributaries to } 30 \\
\text { ppt/saltwater near its mouth at } \\
\text { the Atlantic Ocean) as well as } \\
\text { seasonal hypoxia and anoxia; } \\
\text { political and management } \\
\text { boundaries are also well defined in } \\
\text { the sense that Maryland fisheries } \\
\text { management oversees Maryland } \\
\text { waters of the Chesapeake Bay. }\end{array}$ \\
\hline $\begin{array}{l}\text { Adaptation } \\
\text { (individual or } \\
\text { community level } \\
\text { adaptation or }\end{array}$ & $\begin{array}{l}\text { Individual \& } \\
\text { community } \\
\text { adaptation: } \\
\text { Q'eqchi' }\end{array}$ & $\begin{array}{l}\text { Individual \& } \\
\text { community } \\
\text { adaptation: } \\
\text { individual }\end{array}$ & $\begin{array}{l}\text { Individual \& } \\
\text { community } \\
\text { adaptation: } \\
\text { expansion of }\end{array}$ & $\begin{array}{l}\text { Individual \& } \\
\text { community } \\
\text { adaptation: } \\
\text { evidence for }\end{array}$ & $\begin{array}{l}\text { Individual \& } \\
\text { community } \\
\text { adaptation: } \\
\text { land tenure }\end{array}$ & $\begin{array}{l}\text { Both: Individuals within Maryland } \\
\text { fisheries regularly adapt to } \\
\text { dynamic system conditions and } \\
\text { respond to sociopolitical inputs }\end{array}$ \\
\hline
\end{tabular}




\begin{tabular}{|c|c|c|c|c|c|c|}
\hline $\begin{array}{l}\text { adaptation through } \\
\text { policy, or both) }\end{array}$ & $\begin{array}{l}\text { households as } \\
\text { primary unit of } \\
\text { social and } \\
\text { economic } \\
\text { decision } \\
\text { making; health } \\
\text { and wealth as } \\
\text { important } \\
\text { measures of } \\
\text { success. }\end{array}$ & $\begin{array}{l}\text { gardeners } \\
\text { decide } \\
\text { management } \\
\text { practices; } \\
\text { local } \\
\text { gardening } \\
\text { association } \\
\text { influences } \\
\text { decisions; } \\
\text { success is } \\
\text { measured } \\
\text { through yield } \\
\text { and taste of } \\
\text { products }\end{array}$ & $\begin{array}{l}\text { agriculturally } \\
\text { used areas; } \\
\text { investment of } \\
\text { labor; success } \\
\text { measured in } \\
\text { wealth (size of } \\
\text { farm and amount } \\
\text { of land) }\end{array}$ & $\begin{array}{l}\text { frequent } \\
\text { interregional } \\
\text { trade during } \\
\text { the Bronze Age } \\
\text { in SW Germany } \\
\text { points to swift } \\
\text { distribution of } \\
\text { ideas and } \\
\text { technologies as } \\
\text { means for } \\
\text { adaptation }\end{array}$ & $\begin{array}{l}\text { maintained by } \\
\text { lineages from } \\
\text { nearby } \\
\text { settlements; } \\
\text { management } \\
\text { information } \\
\text { passed orally } \\
\text { and via } \\
\text { experience; } \\
\text { success } \\
\text { measured by } \\
\text { both obtaining } \\
\text { a good harvest } \\
\text { and by leaving } \\
\text { enough clams } \\
\text { behind to } \\
\text { maintain the } \\
\text { population }\end{array}$ & $\begin{array}{l}\text { (regulatory restrictions, catch } \\
\text { limits, etc.) by adhering to } \\
\text { fluctuating rules and laws; job } \\
\text { satisfaction and the ability to feed } \\
\text { one's family define success }\end{array}$ \\
\hline $\begin{array}{l}\text { Out-of-equilibrium } \\
\text { conditions within } \\
\text { the studied system } \\
\text { (yes or no) }\end{array}$ & $\begin{array}{l}\text { Yes: swidden } \\
\text { systems } \\
\text { worldwide } \\
\text { suggest } \\
\text { increased } \\
\text { biodiversity } \\
\text { (Balée 2006), } \\
\text { and possibility } \\
\text { of increased } \\
\text { hunting returns } \\
\text { in swidden } \\
\text { fallows due to } \\
\text { increased food } \\
\text { sources for } \\
\text { prey, source- } \\
\text { sink dynamics, } \\
\text { or sustainable } \\
\text { off-takes (Bird } \\
\text { 2015). }\end{array}$ & $\begin{array}{l}\text { Yes: the } \\
\text { gardeners are } \\
\text { creating } \\
\text { locally } \\
\text { enhanced } \\
\text { carrying } \\
\text { capacities; } \\
\text { highly diverse } \\
\text { plant } \\
\text { communities } \\
\text { in the } \\
\text { different } \\
\text { gardens lead } \\
\text { to a high plant } \\
\text { biodiversity } \\
\text { and in turn } \\
\text { create } \\
\text { habitats for } \\
\text { fauna }\end{array}$ & $\begin{array}{l}\text { Yes: woodland is } \\
\text { turned into fields, } \\
\text { meadows and } \\
\text { bushland; } \\
\text { forested areas } \\
\text { massively } \\
\text { declines; energy } \\
\text { input by man- } \\
\text { power for } \\
\text { clearing } \\
\text { forest/building } \\
\text { terraces etc. }\end{array}$ & $\begin{array}{l}\text { Yes: } \\
\text { deforestation, } \\
\text { plowing, } \\
\text { manure } \\
\text { management, } \\
\text { building burial } \\
\text { mounds etc. } \\
\text { changed the } \\
\text { appearance of } \\
\text { landscapes; to } \\
\text { maintain these } \\
\text { states or to } \\
\text { minimize } \\
\text { undesired } \\
\text { effects, a } \\
\text { constant input } \\
\text { of energy was } \\
\text { applied. }\end{array}$ & $\begin{array}{l}\text { Yes: clam } \\
\text { populations } \\
\text { were } \\
\text { maintained at } \\
\text { higher than } \\
\text { natural levels } \\
\text { by creating } \\
\text { habitat and } \\
\text { managing } \\
\text { populations; } \\
\text { clam gardens } \\
\text { require } \\
\text { construction } \\
\text { and } \\
\text { maintenance; } \\
\text { moved } \\
\text { boulders and } \\
\text { cobbles change } \\
\text { the sediment } \\
\text { regime to build } \\
\text { the platform; } \\
\text { regular digging } \\
\text { prevents } \\
\text { sulfide } \\
\text { accumulation } \\
\text { and washes } \\
\text { away fine } \\
\text { particles, } \\
\text { maintaining } \\
\text { sandy habitat }\end{array}$ & $\begin{array}{l}\text { Yes: the current reduced oyster } \\
\text { population may be an out-of- } \\
\text { equilibrium condition created by } \\
\text { combined inputs of overharvest, } \\
\text { habitat loss, and oyster disease } \\
\text { (Wilberg et al., 2011) exacerbated } \\
\text { by warming temperatures } \\
\text { (Mackenzie \& Tarnowski, 2018); } \\
\text { progress in storm water and runoff } \\
\text { management and increased inputs } \\
\text { of oysters via restoration and } \\
\text { aquaculture may contribute to a } \\
\text { path toward an alternate state } \\
\text { (Fulford et al., 2007). }\end{array}$ \\
\hline $\begin{array}{l}\text { Social and natural } \\
\text { feedback effects } \\
\text { within the analyzed } \\
\text { system (yes or no) }\end{array}$ & $\begin{array}{l}\text { Yes: Swidden } \\
\text { fields are } \\
\text { placed } \\
\text { intentionally } \\
\text { with respect to } \\
\text { historical forest }\end{array}$ & $\begin{array}{l}\text { Yes: gardeners } \\
\text { increase soil } \\
\text { fertility, which } \\
\text { enables them } \\
\text { to grow a } \\
\text { diverse set of }\end{array}$ & $\begin{array}{l}\text { Yes: most } \\
\text { probably new } \\
\text { cultivated land } \\
\text { was used due to } \\
\text { rights of } \\
\text { ownership, but }\end{array}$ & $\begin{array}{l}\text { Yes: Socio- } \\
\text { cultural and } \\
\text { technological } \\
\text { developments } \\
\text { (growing } \\
\text { demand for }\end{array}$ & $\begin{array}{l}\text { Yes: larger } \\
\text { clam } \\
\text { populations } \\
\text { would have } \\
\text { positive water } \\
\text { quality and }\end{array}$ & $\begin{array}{l}\text { Yes: policy changes in } 2010 \\
\text { reorganized submerged land } \\
\text { classifications to create larger no- } \\
\text { harvest oyster sanctuaries, reduce } \\
\text { available bottom for public oyster } \\
\text { fisheries, and expand the potential }\end{array}$ \\
\hline
\end{tabular}




\begin{tabular}{|c|c|c|c|c|c|c|}
\hline & $\begin{array}{l}\text { use, local } \\
\text { norms } \\
\text { regarding } \\
\text { nominal land } \\
\text { 'ownership', } \\
\text { past } \\
\text { productivity, } \\
\text { and expected } \\
\text { future benefits; } \\
\text { visible spatial } \\
\text { mosaics }\end{array}$ & $\begin{array}{l}\text { plants, which } \\
\text { provide } \\
\text { habitat to } \\
\text { fauna, which } \\
\text { increases the } \\
\text { biodiversity of } \\
\text { the area; } \\
\text { combination } \\
\text { of up to } 100 \\
\text { gardens with } \\
\text { different } \\
\text { management } \\
\text { practices in } \\
\text { one } \\
\text { association } \\
\text { creates a } \\
\text { mosaic of } \\
\text { plant and } \\
\text { animal } \\
\text { communities }\end{array}$ & $\begin{array}{l}\text { also commons } \\
\text { existed which } \\
\text { had to be dealt } \\
\text { with by } \\
\text { agreements } \\
\text { (which parts of } \\
\text { the mountains \& } \\
\text { terraces could be } \\
\text { used when); } \\
\text { feedback } \\
\text { dynamics } \\
\text { possibly caused } \\
\text { by climatic } \\
\text { problems/crop } \\
\text { failure/erosion } \\
\text { problems that led } \\
\text { to adjustment in } \\
\text { the use of the } \\
\text { mountain fields } \\
\text { and terraces }\end{array}$ & $\begin{array}{l}\text { fields, lumber } \\
\text { and fuel) are } \\
\text { likely reasons } \\
\text { for intensified } \\
\text { land use and } \\
\text { erosion, } \\
\text { especially } \\
\text { during the } \\
\text { Early Bronze } \\
\text { Age (Henkner } \\
\text { et al. 2017, } \\
\text { Dreibrodt et al. } \\
\text { 2010; Vogt } \\
\text { 2014). Soil } \\
\text { degradation } \\
\text { may then have } \\
\text { encouraged a } \\
\text { shift towards } \\
\text { more extensive } \\
\text { land use and } \\
\text { the settlement } \\
\text { of former } \\
\text { "marginal" } \\
\text { areas. } \\
\text { Consequently, } \\
\text { expanding } \\
\text { settlement } \\
\text { networks } \\
\text { would have } \\
\text { become more } \\
\text { complex as } \\
\text { well, } \\
\text { potentially } \\
\text { promoting } \\
\text { socio-cultural } \\
\text { changes in } \\
\text { turn. }\end{array}$ & $\begin{array}{l}\text { habitat } \\
\text { impacts for the } \\
\text { ecosystem at } \\
\text { large and } \\
\text { would improve } \\
\text { the resilience } \\
\text { of the coupled } \\
\text { human-ocean } \\
\text { systems; larger } \\
\text { clam harvests } \\
\text { would support } \\
\text { larger human } \\
\text { settlements, } \\
\text { who would be } \\
\text { better able to } \\
\text { maintain large } \\
\text { clam gardens. }\end{array}$ & $\begin{array}{l}\text { development of oyster } \\
\text { aquaculture; more oysters in the } \\
\text { water, presumably increase many } \\
\text { ecosystem services, and a much } \\
\text { larger number of active oyster } \\
\text { aquaculture operations, which also } \\
\text { could enhance ecosystem services. }\end{array}$ \\
\hline $\begin{array}{l}\text { Evidence of } \\
\text { emergence (local } \\
\text { interactions, self- } \\
\text { organization into } \\
\text { hierarchies, } \\
\text { unexpected/unex- } \\
\text { plainable system- } \\
\text { level properties) } \\
\text { within the } \\
\text { investigated system } \\
\text { (yes or no) }\end{array}$ & $\begin{array}{l}\text { Yes: village } \\
\text { labor exchange } \\
\text { networks } \\
\text { exhibit } \\
\text { unexpected } \\
\text { levels of } \\
\text { hierarchy and } \\
\text { connectivity } \\
\text { without top- } \\
\text { down } \\
\text { coordination }\end{array}$ & $\begin{array}{l}\text { Yes: local } \\
\text { networks } \\
\text { between the } \\
\text { gardeners } \\
\text { within an } \\
\text { association; } \\
\text { regional } \\
\text { networks } \\
\text { between the } \\
\text { spokesper- } \\
\text { sons of each } \\
\text { association; a } \\
\text { (flat) } \\
\text { hierarchy } \\
\text { exists } \\
\text { between the } \\
\text { individual }\end{array}$ & $\begin{array}{l}\text { Yes: system is } \\
\text { dominated by } \\
\text { local interaction } \\
\text { of the farmers; } \\
\text { differences } \\
\text { between "richer" } \\
\text { and poorer" } \\
\text { farmers (amount } \\
\text { of land use and } \\
\text { invested labor); } \\
\text { centralized } \\
\text { control (or at } \\
\text { least } \\
\text { agreements) } \\
\text { necessary for } \\
\text { commons. }\end{array}$ & $\begin{array}{l}\text { Yes: } \\
\text { settlement } \\
\text { networks may } \\
\text { be clustered } \\
\text { around local or } \\
\text { even regional } \\
\text { nodal points } \\
\text { (e.g. within } \\
\text { trading routes) } \\
\text { and could } \\
\text { comprise a } \\
\text { differentiated } \\
\text { set of } \\
\text { settlement } \\
\text { types (along } \\
\text { with burial } \\
\text { sites, }\end{array}$ & $\begin{array}{l}\text { Yes: landforms } \\
\text { and large clam } \\
\text { populations } \\
\text { emerge from } \\
\text { the clam } \\
\text { garden } \\
\text { management; } \\
\text { communities } \\
\text { located near } \\
\text { highly } \\
\text { productive } \\
\text { clam gardens } \\
\text { would have } \\
\text { experienced } \\
\text { greater food } \\
\text { security and } \\
\text { may have }\end{array}$ & $\begin{array}{l}\text { Yes: recent, locally increased } \\
\text { submerged aquatic vegetation } \\
\text { (SAV) populations may be an } \\
\text { emergent property due to (i) } \\
\text { better storm water, pollution, and } \\
\text { nutrient management at local and } \\
\text { watershed levels and (ii) } \\
\text { potentially increased ecosystem } \\
\text { services provided by oysters via } \\
\text { restoration and aquaculture, } \\
\text { though the relationship between } \\
\text { oyster aquaculture and SAV is } \\
\text { debated (Dumbauld \& McCoy, } \\
\text { 2015; Ferreira \& Bricker, 2016; } \\
\text { Orth et al., 2017). }\end{array}$ \\
\hline
\end{tabular}




\begin{tabular}{|c|c|c|c|c|c|c|}
\hline & & $\begin{array}{l}\text { gardeners, the } \\
\text { spokesper- } \\
\text { sons of the } \\
\text { association } \\
\text { they belong } \\
\text { to, the } \\
\text { regional } \\
\text { networks and } \\
\text { the country- } \\
\text { wide garden } \\
\text { association. }\end{array}$ & & $\begin{array}{l}\text { functional } \\
\text { places, etc.) } \\
\text { which may } \\
\text { have organized } \\
\text { themselves; no } \\
\text { clear evidence } \\
\text { for any kind of } \\
\text { centralized } \\
\text { decision } \\
\text { making in SW } \\
\text { Germany } \\
\text { during the } \\
\text { Bronze Age. }\end{array}$ & $\begin{array}{l}\text { grown larger } \\
\text { over time. }\end{array}$ & \\
\hline $\begin{array}{l}\text { Alternative regimes } \\
\text { possible (yes or no) }\end{array}$ & $\begin{array}{l}\text { Yes: transition } \\
\text { to a grassland } \\
\text { regime due to } \\
\text { cattle ranching } \\
\text { in combination } \\
\text { with political } \\
\text { and economic } \\
\text { factors; villages } \\
\text { exhibit varying } \\
\text { degrees of } \\
\text { socioecological } \\
\text { resilience due } \\
\text { to variation in } \\
\text { environmental } \\
\text { and geographic } \\
\text { recourses, and } \\
\text { historical and } \\
\text { social factors }\end{array}$ & $\begin{array}{l}\text { No (and Yes): } \\
\text { Due to the } \\
\text { German law, } \\
\text { allotment } \\
\text { gardens do } \\
\text { not currently } \\
\text { exhibit } \\
\text { alternative } \\
\text { regimes; but, } \\
\text { food } \\
\text { production } \\
\text { becomes less } \\
\text { important due } \\
\text { to the } \\
\text { availability of } \\
\text { cheap fruit } \\
\text { and } \\
\text { vegetables in } \\
\text { supermarkets } \\
\& \text { farmers } \\
\text { markets }\end{array}$ & $\begin{array}{l}\text { Yes: creation of } \\
\text { mountain fields } \\
\text { and terraces } \\
\text { might have been } \\
\text { caused by a } \\
\text { regime shift } \\
\text { (growing } \\
\text { population); with } \\
\text { a change in the } \\
\text { 20th century to } \\
\text { less agriculture } \\
\text { and more } \\
\text { handicrafts, } \\
\text { industrialization, } \\
\text { \& tourism, the } \\
\text { mountain fields \& } \\
\text { terrace system } \\
\text { was abandoned; } \\
\text { the traditional, } \\
\text { big farms in the } \\
\text { region have } \\
\text { existed since the } \\
\text { 15th century and } \\
\text { point to the } \\
\text { resilience of the } \\
\text { system }\end{array}$ & $\begin{array}{l}\text { Yes: marked } \\
\text { shifts between } \\
\text { lakeshore/ } \\
\text { wetland and } \\
\text { inland/ } \\
\text { terrestrial } \\
\text { habitats from } \\
\text { the Early to } \\
\text { Middle and } \\
\text { Middle to Late } \\
\text { Bronze Age; } \\
\text { differences in } \\
\text { local } \\
\text { chronologies of } \\
\text { cultural and } \\
\text { land use } \\
\text { changes may } \\
\text { indicate } \\
\text { varying levels } \\
\text { of resilience }\end{array}$ & $\begin{array}{l}\text { Yes: with a lack } \\
\text { of active } \\
\text { management, } \\
\text { soil conditions } \\
\text { change, clam } \\
\text { populations } \\
\text { decline, and } \\
\text { other } \\
\text { organisms } \\
\text { increase in } \\
\text { abundance, } \\
\text { leading the } \\
\text { system to shift } \\
\text { from } \\
\text { productive } \\
\text { clam beds to } \\
\text { muddy and } \\
\text { sulfidic flats }\end{array}$ & $\begin{array}{l}\text { Yes: local water quality has } \\
\text { improved in some places; major } \\
\text { storm events can dramatically } \\
\text { revert local improvements back to } \\
\text { what may be considered a largely } \\
\text { unfavored state; sociopolitical } \\
\text { inputs may lead to an alternative } \\
\text { regime in which there is no public } \\
\text { oyster fishery }\end{array}$ \\
\hline $\begin{array}{l}\text { Are there triggers } \\
\text { (material or } \\
\text { symbolic) in the } \\
\text { investigated system } \\
\text { (yes or no) }\end{array}$ & $\begin{array}{l}\text { Yes: material } \\
\text { improvements } \\
\text { in road } \\
\text { infrastructure } \\
\text { trigger regime } \\
\text { shifts towards } \\
\text { market } \\
\text { integration } \\
\text { (Chomitz and } \\
\text { Gray 1995); } \\
\text { recent legal } \\
\text { decisions in } \\
\text { favor of } \\
\text { community } \\
\text { land rights }\end{array}$ & $\begin{array}{l}\text { Yes: World } \\
\text { Wars as } \\
\text { historic } \\
\text { triggers to } \\
\text { start urban } \\
\text { gardens in } \\
\text { Germany due } \\
\text { to food } \\
\text { shortage; } \\
\text { provisioning } \\
\text { of a healthy } \\
\text { free time } \\
\text { activity during } \\
\text { industrializa- } \\
\text { tion promoted }\end{array}$ & $\begin{array}{l}\text { Yes: population } \\
\text { growth leads to } \\
\text { more demand for } \\
\text { food; more } \\
\text { manpower } \\
\text { enables forest } \\
\text { clearing for fields; } \\
\text { the Biblical duty } \\
\text { of Christians to } \\
\text { tame the } \\
\text { wilderness } \\
\text { (forests and } \\
\text { mountains) as a } \\
\text { symbolic trigger. }\end{array}$ & $\begin{array}{l}\text { Yes: material } \\
\text { trigger "Bronze } \\
\text { metallurgy" led } \\
\text { to a } \\
\text { reevaluation of } \\
\text { areas; Middle } \\
\text { Bronze Age } \\
\text { abandonment } \\
\text { of the } \\
\text { lakeshores is } \\
\text { usually } \\
\text { correlated with } \\
\text { climate } \\
\text { deterioration } \\
\text { and rising }\end{array}$ & $\begin{array}{l}\text { Yes: the } \\
\text { European- } \\
\text { inspired legal } \\
\text { system made } \\
\text { management } \\
\text { strategies } \\
\text { illegal; recently } \\
\text { the National } \\
\text { Park Service } \\
\text { has considered } \\
\text { allowing } \\
\text { subsistence } \\
\text { clam gardening } \\
\text { in some areas, } \\
\text { and many }\end{array}$ & $\begin{array}{l}\text { Yes: both material } \\
\text { (climatic/weather) and symbolic } \\
\text { (policy) triggers may affect the } \\
\text { system. Major weather events can } \\
\text { destroy or alter estuarine habitat } \\
\text { and coastal communities, and } \\
\text { extended weather patterns during } \\
\text { a single season can hinder } \\
\text { recruitment and survival; the } \\
\text { system has been affected by far- } \\
\text { reaching } 2010 \text { policy changes } \\
\text { designed to catalyze oyster } \\
\text { aquaculture and trigger a regime } \\
\text { shift into a self-sustaining oyster } \\
\text { population. }\end{array}$ \\
\hline
\end{tabular}


p. 20

\begin{tabular}{|c|c|c|c|}
\hline $\begin{array}{l}\text { could be } \\
\text { symbolic } \\
\text { triggers for the } \\
\text { development of } \\
\text { novel forms of } \\
\text { community } \\
\text { land } \\
\text { management }\end{array}$ & $\begin{array}{l}\text { among others } \\
\text { by factory } \\
\text { owners } \\
\text { (Nilsen 2014, } \\
\text { Keshavarz and } \\
\text { Bell 2016); } \\
\text { recent } \\
\text { symbolic } \\
\text { triggers: wish } \\
\text { to be } \\
\text { outdoors and } \\
\text { experience } \\
\text { nature }\end{array}$ & water levels & $\begin{array}{l}\text { states and the } \\
\text { US Army Corps } \\
\text { of Engineers } \\
\text { have } \\
\text { implemented } \\
\text { systems of } \\
\text { permitting and } \\
\text { promoting } \\
\text { bottom } \\
\text { management } \\
\text { for } \\
\text { aquaculture; a } \\
\text { material } \\
\text { trigger is the } \\
\text { initial moving } \\
\text { of stones to } \\
\text { build the } \\
\text { bulwark }\end{array}$ \\
\hline
\end{tabular}

